\title{
Soil carbon sequestrations by nitrogen fertilizer application, straw return and no-tillage in China's cropland
}

\author{
FEI LU, XIAOKE WANG, BING HAN, ZHIYUN OUYANG, XIAONAN DUAN, \\ HUA ZHENG and HONG MIAO \\ Research Center for Eco-Environmental Sciences, The Chinese Academy of Sciences, Shuangqinglu 18, Beijing 100085, China
}

\begin{abstract}
Soil as the largest global carbon pool has played a great role in sequestering the atmospheric carbon dioxide $\left(\mathrm{CO}_{2}\right)$. Although global carbon sequestration potentials have been assessed since the 1980s, few investigations have been made on soil carbon sequestration (SCS) in China's cropland. China is a developing country and has a long history of agricultural activities. Estimation of SCS potentials in China's cropland is very important for assessing the potential measures to prevent the atmospheric carbon rise and predicting the atmospheric $\mathrm{CO}_{2}$ concentration in future. After review of the available results of the field experiments in China, relationships between SCS and nitrogen fertilizer application, straw return and no-tillage (NT) practices were established for each of the four agricultural regions. According to the current agricultural practices and their future development, estimations were made on SCS by nitrogen fertilizer application, straw return and NT in China's cropland. In the current situation, nitrogen fertilizer application, straw return and zero tillage can sequester $5.96,9.76$ and $0.800 \mathrm{Tg} C$ each year. Carbon sequestration potential will increase to $12.1 \mathrm{Tg} \mathrm{C} \mathrm{yr}^{-1}$ if nitrogen is fertilized on experts' recommendations. The carbon sequestration potentials of straw return and NT can reach 34.4 and $4.60 \mathrm{TgC}^{-1}$ when these two techniques are further popularized. In these measures, straw return is the most promising one. Full popularization of straw return can reduce $5.3 \%$ of the $\mathrm{CO}_{2}$ emission from fossil fuel combustion in China in 1990, which meets the global mean $\mathrm{CO}_{2}$ reduction requested by the Kyoto Protocol (5.2\%). In general, if more incentive policies can be elaborated and implemented, the SCS in China's cropland will be increased by about two times. So, popularization of the abovementioned agricultural measures for carbon sequestration can be considered as an effective tool to prevent the rapid rise of the atmospheric $\mathrm{CO}_{2}$ in China.
\end{abstract}

Keywords: carbon sequestration, China, cropland, nitrogen fertilizer, no-tillage, soil organic carbon, straw return

Received 4 April 2008; revised version received 31 July 2008 and accepted 5 August 2008

\section{Introduction}

With the increasing concern about the global climate change, a series of measures to reduce the anthropogenic emission of carbon dioxide $\left(\mathrm{CO}_{2}\right)$ have been strongly recommended under the United Nations Framework Convention on Climate Change (UNFCCC). Besides reduction in $\mathrm{CO}_{2}$ emission from fossil fuel combustion, measures to increase carbon storage in

Correspondence: Xiaoke Wang, tel. + 86106294 3822, fax + 8610 6294 3822, e-mail: wangxk@rcees.ac.cn terrestrial ecosystems are also promoted as important options. Human disturbances in the terrestrial ecosystem, such as deforestation and cropland cultivation, have contributed a large quantity of carbon accumulation in the atmosphere. In the 1990s, the annual carbon release from land use change amounted to $1.6 \mathrm{PgC}_{\mathrm{Cr}}{ }^{-1}$, which was about $25 \%$ of the carbon emission from fossil fuel burning (IPCC, 2000). Conversion of natural lands to agricultural lands causes depletion of the soil organic carbon (SOC) pool by as much as $60 \%$ in the temperate regions and $75 \%$ or more in the tropics (Lal, 2004a). Nowadays, a considerable soil carbon loss from 
croplands is still continuing in many places of the world, such as England and Whales (Bellamy et al., 2005), China (Li et al., 2003), USA (Hurtt et al., 2002) and Europe (Janssens et al., 2003). Soil carbon loss from croplands is mainly caused by reduction in carbon input (e.g. harvest of biomass) and breaking down of the soil aggregate which protects soil carbon from decomposition (e.g. tillage). As the current soil carbon density in China's cropland is low due to long-term carbon loss from soils ( $\mathrm{Li}$ et al., 2003), measures to reverse the processes of stimulating soil carbon loss will sequester the atmospheric carbon into the soil. It has been suggested in many researches that proper management of croplands may sequester a considerable quantity of the atmospheric carbon (IPCC, 2001; Lal, 2004b; Smith, 2004).

Some activities, including agricultural practices, are proposed in the Kyoto Protocol, an international agreement for reducing $\mathrm{CO}_{2}$ emission by $5.2 \%$ from 1990 emission level, for slowing down the rise of the atmospheric carbon. The Marrakech Accords, resulting from the Seventh Conference of the Parties (COP7) to the UNFCCC, allow biospheric carbon sinks and sources to be included in the attempts to meet the Quantified Emission Limitation or Reduction Commitments (QELRCs) for the first commitment period (2008-2012). Therefore, the parties included in Annex I to the Convention pay great attention to carbon sequestration in agricultural soils. The carbon sequestration potentials in croplands have been estimated for the world (Lal \& Bruce, 1999), the USA (Lal et al., 1998) and Europe (Smith et al., 1998).

China, as the most populous country, has contributed more than $10 \%$ of the global $\mathrm{CO}_{2}$ emission from fossil fuel combustion and cement production. Although China, for the time being, has no obligation for reducing $\mathrm{CO}_{2}$ emission according to the Kyoto Protocol, it is still absolutely necessary for China to assess all the possible alternatives to stabilize the atmospheric $\mathrm{CO}_{2}$. Furthermore, as China is the largest developing country in the world, its potential to sequester $\mathrm{CO}_{2}$ will be representative for other developing countries. China is also a large agricultural country, with $60 \%$ of its population living on agriculture. China's cropland accounts for $13 \%$ of the national land (Editorial Board of China Agriculture Yearbook, 2005) and 9.8\% of the global cropland (FAO Statistics Division, 2007). Its capacity of storing carbon is meaningful for reducing $\mathrm{CO}_{2}$ emission in both national and global scales. Because China has a long history of cultivation, and there have been low crop residue return and fertilizer application, soil carbon in the cropland of China has dropped to a relatively low level (Li et al., 2003). In recent years, with China's rapid economic development, more investment has been made in crop production, and as a result, nitrogen fertilizer application has been increased, and more machines introduced and developed for promotion of straw return and no-tillage (NT) practices. In addition, the crop residue used as fuel or forage is much less than that before the 1980s. All these will provide prospective opportunities for sequestering the atmospheric carbon in China's cropland soils.

Soil carbon storage depends on the balance between carbon input and output. Optimizing agricultural managements can increase soil carbon by increasing carbon input and/or decreasing carbon output. Fertilizer application can raise crop yield as well as biomass, which will increase biomass input into soil from crop residues and roots. Straw return can increase carbon input to soil from crop residues. NT can reduce disturbances on the soil and therefore prevent soil carbon release. Available field experiment results have widely proved that these measures, such as fertilizer application, straw return and NT, can increase soil carbon and sequester carbon from the atmosphere. Halvorson et al. (1999) reported that increasing nitrogen fertilizer rate would increase SOC levels in the $0-7.5 \mathrm{~cm}$ soil depth after 11 years cropping. The same result was also found in Canada (Dumanski et al., 1998). Rasmussen \& Parton (1994) and others (e.g. Cole et al., 1993) stated that SOC responded linearly to the increasing rates of residues or carbon additions in both short- and long-term experiments. Using a global database of 67 long-term agricultural experiments, comprising 276 paired treatments, West \& Post (2002) pointed out that, on average, a change from conventional tillage (CT) to NT could sequester $14-57 \mathrm{~g} \mathrm{C} \mathrm{m}^{-2} \mathrm{yr}^{-1}$.

The soil carbon sequestration (SCS) potential (of nitrogen fertilizer application, straw return and NT) in croplands has been estimated for the whole world and for some regions. Lal (1997) simply estimated that the global cropland soil sequestration potential would reach $200 \mathrm{TgC} \mathrm{yr}^{-1}$ for residue return and $1500 \mathrm{TgC} \mathrm{yr}^{-1}$ for conservation tillage, respectively. Later, Lal \& Bruce (1999) made a more conservative sequestration estimate of $150 \pm 175 \mathrm{TgC}^{-1}$ with conservation tillage and crop residue return. Smith et al. (1998) suggested that adoption of conservation tillage had the potential to sequester about $23 \mathrm{TgC} \mathrm{yr}^{-1}$ in the European Union or about $43 \mathrm{TgC} \mathrm{yr}^{-1}$ in a wider area of Europe including the former Soviet Union. Based on the available statistical data and field experiment results, Freibauer et al. (2004) made the estimation that the SCS potentials were $28 \mathrm{TgC} \mathrm{yr}^{-1}$ for NT, and $26 \mathrm{TgCyr}^{-1}$ for crop residue return, respectively, if all the croplands in Europe were taken into account. For the USA, Follett (2001) estimated that the SCS potentials were $6-8 \mathrm{TgC}^{-1}$ for fertilizer management, 17.8-35.7 $\mathrm{TgC}^{-1}$ for conservation tillage and $11-56 \mathrm{TgC}^{-1}{ }^{-1}$ for residue management. 
Recently, some models were used in China to estimate the SCS in croplands. Denitrification/Decomposition (DNDC) is a widely used process-based biogeochemical model for simulating soil carbon and nitrogen changes in agricultural soils. With the help of this model, Tang et al. (2006) predicted that the soil carbon loss in China's cropland would be partly reversed if straw return and NT practices were expanded widely. Using a coupled remote sensing- and process-based ecosystem model of CEVSA (Carbon Exchange between Vegetation, Soil and Atmosphere), Yan et al. (2007) estimated that there was $32.5 \mathrm{TgC}^{-1}$ to be sequestered in croplands if NT was adopted on $50 \%$ of the arable lands, and $50 \%$ of the crop residue was returned to soils. Unfortunately, these results are criticized for the models that are calibrated against few or no field experimental data, and the supposed scenarios are short of spatial distributed agricultural practices.

Fertilizer application, straw return and NT are practices being popularized in China. A series of field experiments have been made about the effects of agricultural practices on soil carbon changes. In this study, after widely collecting field experimental data in China on soil carbon changes under nitrogen fertilizer application, straw return and NT practices, we established relationships between soil carbon changes and the agricultural practices in different agricultural regions, and estimated the SCS under the current and future scenarios.

\section{Materials and methods}

\section{Approach}

In this study, two scenarios were designed for estimating the current SCS and predicting the potential SCS. The current scenarios were based on the extent of nitrogen fertilizer application, straw return and NT applied in the current situation, while the potential scenarios were set upon the condition that all the measures were promoted with the maximum efforts.

For each carbon sequestration measure, SCS, including the current SCS and potential SCS, was calculated by multiplying the SCS rate by the area in which the SCS measures were implemented at the provincial level, and then the sum for the whole country was found.

$$
\mathrm{SCS}=\sum\left(\mathrm{SCSR}_{i} \times A_{i}\right) \times 10^{-9},
$$

where SCS is the total soil carbon sequestration $\left(\mathrm{TgC} \mathrm{yr}^{-1}\right), \mathrm{SCSR}_{i}$ is the soil carbon sequestration rate ( $\mathrm{kgCha}{ }^{-1} \mathrm{yr}^{-1}$ ) and $A_{i}$ is the cropland area (ha) on which a carbon sequestration measure is adopted for province $i$.

The methods for estimating $\mathrm{SCSR}_{i}$ vary with the measures considered, depending on the available field experimental and statistical data as well as the relation- ship between $\mathrm{SCSR}_{i}$ and the extent of implementation of the measures.

For fertilizer application and straw return, it is assumed that $\mathrm{SCSR}_{i}$ is linearly related to the amount of the fertilizer applied or straw returned, respectively.

$$
\begin{array}{ll}
\operatorname{SCSR}_{i}=a_{i} \times F_{i}+b_{i} & \text { for fertilizer application } \\
\operatorname{SCSR}_{i}=a_{i} \times S_{i}+b_{i} & \text { for straw return }
\end{array},
$$

where $a_{i}$ is the slope and $b_{i}$ is the intercept of the linear equation, and $F_{i}\left(\mathrm{kgNha}^{-1}\right)$ and $S_{i}\left(\mathrm{tha}^{-1}\right)$ are the amount of fertilizer applied and straw returned per hectare of cropland, respectively.

For NT practice, $\mathrm{SCSR}_{i}$, expressed in unit of $\mathrm{kgCha}{ }^{-1} \mathrm{yr}^{-1}$, is derived from the average of the SCS rates reported from the field experiments, because there is no information about the intensity of tillage reduced.

For $\mathrm{SCSR}_{i}$ estimation, due to the limit of experimental data, we could not give all the parameters $\left(a_{i}\right.$ and $b_{i}$ for fertilizer application and straw return, and $\mathrm{SCSR}_{i}$ for NT) for each province. So, we divided China into four regions: namely Northeast China (Region I), North China (Region II), Northwest China (Region III) and South China (Region IV) according to the geographic differences in climate, crop species and cultivation (Fig. 1, Table 1). From field experimental data, we could calculate $\mathrm{SCSR}_{i}$. For each agricultural region, the parameters of $a_{i}$ and $b_{i}$ for fertilizer application and straw return were obtained by fitting the regression formula [Eqn (2)] between the SCSR and their corresponding amounts of the fertilizer applied or straw returned. For NT, the SCSR for each agricultural region was averaged over all SCSR within it.

In our study, only the data from experiments on rice, wheat and maize were taken to examine the correlations between the carbon sequestration rate and the amount of nitrogen fertilizer application or straw returned. So, when we discuss the carbon sequestration of nitrogen fertilizer application and straw return, $A_{i}$ is constricted in the area of the cropland where rice, wheat or maize is planted. In the scenarios of nitrogen fertilizer application and the potential scenario of straw return, carbon sequestration measures covered all the croplands of paddy rice, wheat and maize, so $A_{i}$ could be obtained as shown in formula (3):

$$
A_{i}=\mathrm{CAT}_{i} \times \sum \mathrm{SA}_{i j} / \mathrm{SAT}_{i},
$$

where $\mathrm{SAT}_{i}$ is the total sown area of all the crops in province $i$ in 2003, while $\mathrm{CAT}_{i}$ is the total cropland area; $\mathrm{SA}_{i j}$ is the sown area of crop $j$ in province $i$, crop $j$ can be rice, wheat or maize.

In the current scenario of straw return, the carbon sequestration measure was adopted in only a part of the cropland where rice, wheat or maize was planted. We identified the proportion of the cropland where straw 

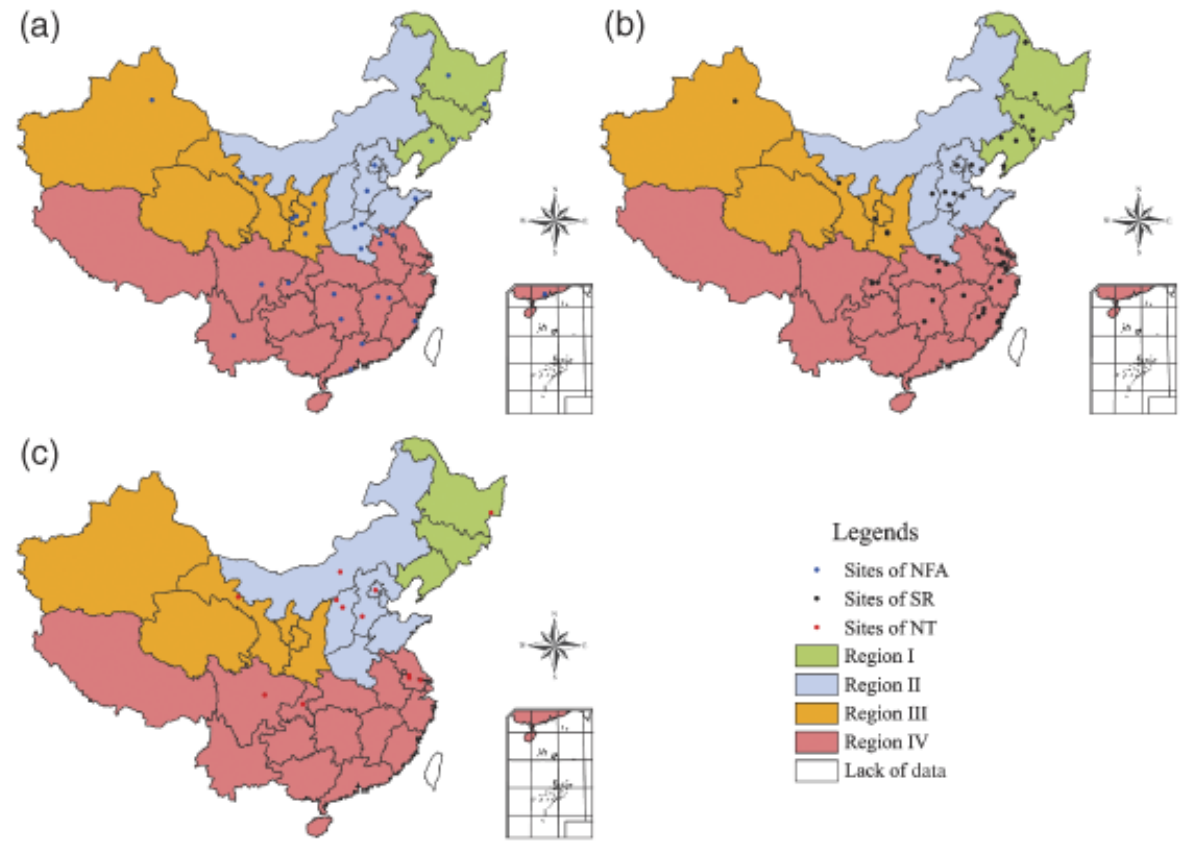

Fig. 1 (a) Experimental sites for nitrogen fertilizer application (NFA), (b) straw return (SR) and (c) no-tillage (NT). The agricultural regions are (I) Northeast China, (II) North China, (III) Northwest China and (IV) South China. (The data of Hong Kong Special Administrative Region, Macao Special Administrative Region and Taiwan Province were not included.)

Table 1 Agricultural regions in China

\begin{tabular}{|c|c|c|c|c|}
\hline Region & Name & $\begin{array}{l}\text { Provinces (including municipalities, } \\
\text { autonomous regions) }\end{array}$ & $\begin{array}{l}\text { Number of crops } \\
\text { sown per year }\end{array}$ & Major crops \\
\hline I & Northeast China & Heilongjiang, Jilin, Liaoning & Single crop & $\begin{array}{l}\text { Maize, soybean rice and } \\
\text { spring wheat }\end{array}$ \\
\hline II & North China & $\begin{array}{l}\text { Beijing, Tianjin, Hebei, Shaanxi, Inner Mongolia, } \\
\text { Henan, Shandong }\end{array}$ & Double crop & Maize and winter wheat \\
\hline III & Northwest China & Shaanxi, Gansu, Ningxia, Qinghai, Xinjiang & Single crop & Maize and winter wheat \\
\hline IV & South China & $\begin{array}{l}\text { Jiangsu, Anhui, Shanghai, Zhejiang, Fujian, } \\
\text { Hubei, Hunan, Guangdong, Guangxi, } \\
\text { Chongqing, Sichuan, Guizhou, Yunnan, Tibet }\end{array}$ & Double crop & $\begin{array}{l}\text { Winter wheat and } \\
\text { paddy rice }\end{array}$ \\
\hline
\end{tabular}

The data of Hong Kong Special Administrative Region, Macao Special Administrative Region and Taiwan Province were not included.

was returned as popularization index (PI). $A_{i}$ in the current scenario could be obtained with formula (4).

$$
A_{i}=\mathrm{CAT}_{i} \times \sum \mathrm{SA}_{i j} / \mathrm{SAT}_{i} \times \mathrm{PI}_{i},
$$

where $\mathrm{PI}_{i}$ is the popularization index of province $i$. The value of $\mathrm{PI}$ is given to each province.

For the scenarios of NT, $A_{i}$ is set directly in accordance with the relative statistics and scenarios description.

\section{Field data source and analysis}

Field experimental data source. In China, field experiments on soil carbon changes were scarcely carried out in the past, and have just begun to be made in recent years.
From the Database of SOC Experiments in Agricultural Soils in China (a database built on the basis of 93 published papers or monographs covering the results of the field experiments that lasted for more than 3 years, and updated in February 2008), 220 pairs of data were gathered to estimate the carbon sequestration rates. There were 84 paired data for fertilizer application from 28 sites, 117 paired data for straw return from 45 sites and 19 paired data for NT from 12 sites (Fig. 1, Tables A1-A3). The 84 pairs of long-term experimental data of nitrogen fertilizer application (Table A1) and the 117 pairs of data from long-term straw return experiments (Table A2) showed an increasing trend of SCSR with higher amount of nitrogen fertilized or straw returned to the unit 
area of croplands in each of the four agricultural regions. All the 19 pairs of data of NT experiments indicated that NT was helpful to the SCS (Table A3).

In these experimental data, SOC was measured in different years after the field experiment began. From the SOC, we can calculate $\mathrm{SCSR}_{i}$ for each site.

SOC density. SOC density can be calculated as follows:

$$
\mathrm{SOCD}=\mathrm{SOCC} \times \mathrm{BD} \times H,
$$

where SOCD and SOCC are the SOC density $\left(\mathrm{kg} \mathrm{Cha}^{-1}\right)$ and SOC concentration $\left(\mathrm{g} \mathrm{kg}^{-1}\right)$, respectively, $\mathrm{BD}$ is the soil bulk density, and $H$ is the thickness of the cultivated layer in croplands. We took a 20 -cm-thick layer for this study. In this study, the bulk density was adopted from the Chinese Soil Database (built by Institute of Soil Science, Chinese Academy of Sciences, available online at http://www.soil.csdb.cn/) and Xu et al. (2003) for the same species of soil if it was not available in the original references about the SOC changes in croplands.

Changes in SOC density. SOC changes can be calculated as follows:

$$
\mathrm{DSOC}=\left(\mathrm{SOCD}_{t}-\mathrm{SOCD}_{0}\right) / t
$$

where $\mathrm{DSOC}$ is the annual SOC density change $\left(\mathrm{kgCha}^{-1} \mathrm{yr}^{-1}\right), \mathrm{SOCD}_{t}$ and $\mathrm{SOCD}_{0}$ are the SOC density at the end and beginning of the experiment $\left(\mathrm{kgCha}{ }^{-1}\right)$, respectively, and $t$ is the duration of the experiment (years).

SCS rate. The SCS rate can be calculated for each paired data as the difference between the annual SOC density changes with and without the carbon sequestration measures considered:

$$
\mathrm{SCSR}_{k}=\mathrm{DSOC}_{k 1}-\mathrm{DSOC}_{k 0},
$$

where $\mathrm{SCSR}_{k}$ is the SCS rate for each paired data $\left(\mathrm{kgCha}^{-1} \mathrm{yr}^{-1}\right)$, and $\mathrm{DSOC}_{k 1}$ and $\mathrm{DSOC}_{k 0}$ are the annual SOC density change with and without implementation of the measures considered $\left(\mathrm{kgCha}^{-1} \mathrm{yr}^{-1}\right)$. Both $\mathrm{DSOC}_{k 1}$ and $\mathrm{DSOC}_{k 0}$ can be calculated by formula (6).

\section{Statistical data and scenario}

In the Agricultural Yearbook of China, there are data of the cropland area, sown area, crop yield and fertilizer application available for each province of China.

Fertilizer application. In the current scenario, the amount of fertilizer applied $\left(\mathrm{FC}_{i}\right)$ was calculated to be the sum of the total nitrogen and $30 \%$ of the compound fertilizer application for each province ( $\mathrm{Lu}, 2004)$. The amount of nitrogen fertilizer application to the unit area of cropland $\left(\mathrm{FO}_{i}\right)$ in each province could be obtained with formula (8):

$$
F 0_{i}=\mathrm{FC}_{i} / \mathrm{CAT}_{i},
$$

where $F 0_{i}\left(\mathrm{~kg} \mathrm{Nha}^{-1} \mathrm{yr}^{-1}\right)$ is the amount of nitrogen fertilized to the unit area of cropland in province $i, \mathrm{FC}_{i}$ is the total amount of nitrogen fertilizer application for all the crops in province $i$ and $\mathrm{CAT}_{i}$ is the total area of the cropland for all the crops in province $i$. Both $\mathrm{FC}_{i}$ and $\mathrm{CAT}_{i}$ are from China Agriculture Yearbook.

Although nitrogen fertilizer of high rates is applied in some regions of China, the rates are still lower than those in the developed countries when the high multicropping index is taken into account (Li et al., 2001). The potential scenario of nitrogen fertilizer application was set according to the optimum amount of nitrogen fertilizer application for each crop recommended by agricultural experts $\left(\mathrm{FR}_{j}\right)$. In accordance with the sown area of the three cereal crops and the application amount recommended by the experts, we get the potential amount of nitrogen fertilizer application in each province from formula (9):

$$
\mathrm{FP}_{i}=\sum \mathrm{SA}_{i j} \times \mathrm{FR}_{j}
$$

where $\mathrm{FP}_{i}$ is the potential (also recommended) amount of synthetic nitrogen application of province $i ; \mathrm{FR}_{j}$ is the recommended amount of nitrogen fertilizer application to each hectare of the sown area of crop $j$, crop $j$ can be rice, wheat or maize. The value of $\mathrm{FR}_{j}$ is $225 \mathrm{~kg} \mathrm{~N} \mathrm{ha}^{-1}$ for paddy rice and wheat and $250 \mathrm{~kg} \mathrm{Nha}^{-1}$ for maize (Ton et al., 2003; Shen et al., 2004; Qin, 2007).

The potential amount of nitrogen fertilizer application to each hectare of cropland $\left(\mathrm{Fp}_{i}\right)$ can be obtained from formula (10).

$$
\mathrm{Fp}_{i}=\mathrm{FP}_{i} / A_{i}
$$

Straw return. The total amount of straw of rice, wheat and maize in each province can be estimated with formula (11):

$$
\mathrm{ST}_{i}=\sum Y_{i j} \times \mathrm{SGR}_{j}
$$

where $\mathrm{ST}_{i}$ is the total amount of straw of rice, wheat and maize; $Y_{i j}$ is the yield of crop $j$ in province $i$; and $\mathrm{SGR}_{j}$ is the straw-grain ratio for crop $j$, crop $j$ can be rice, wheat or maize.

The $\mathrm{SGR}_{j}$ for each crop was adopted from Assessment of Biomass Resource Availability in China (MOA/DOE Project Expert Team, 1998). It is 0.623 for paddy rice, 1.366 for wheat and 2 for maize. According to Liu et al. (2001) and referring to other reports (The Center for Agricultural Technology Popularization of China 2001; Zeng et al., 2002), it is technically possible to return $100 \%$ of the straw of rice, wheat and maize to the cropland. The amount of straw returned to each hectare of cropland is $S_{i}$ (Table 2).

$$
S_{i}=\mathrm{ST}_{i} / A_{i}
$$


Table 2 Straw return and its carbon sequestration in soil

\begin{tabular}{|c|c|c|c|c|c|c|c|c|c|}
\hline \multirow[b]{2}{*}{ Province } & \multirow[b]{2}{*}{$\mathrm{PI}_{i}$} & \multicolumn{2}{|c|}{$A_{i}\left(10^{3} \mathrm{ha}\right)$} & \multirow{2}{*}{$\begin{array}{l}\text { Straw returned } \\
\text { to unit area of } \\
\text { cropland, } S_{i} \\
\left(\mathrm{t} \mathrm{ha}^{-1} \mathrm{yr}^{-1}\right)\end{array}$} & \multicolumn{2}{|c|}{$\begin{array}{l}\text { Straw returned } \\
\left(10^{6} \mathrm{tyr}^{-1}\right)\end{array}$} & \multirow{2}{*}{$\begin{array}{l}\text { Soil carbon } \\
\text { sequestration } \\
\text { rates } \\
\left(\mathrm{kgCha}^{-1} \mathrm{yr}^{-1}\right)\end{array}$} & \multicolumn{2}{|c|}{$\begin{array}{l}\text { Soil carbon } \\
\text { sequestration } \\
\left(\mathrm{TgC} \mathrm{yr}^{-1}\right)\end{array}$} \\
\hline & & Current & Potential & & Current & Potential & & Current & Potential \\
\hline Beijing & 47.3 & 59.3 & 125.3 & 7.20 & 0.426 & 0.902 & 474 & 0.0281 & 0.0594 \\
\hline Tianjin & 47.3 & 96.3 & 203.5 & 8.95 & 0.862 & 1.82 & 545 & 0.0525 & 0.111 \\
\hline Hebei & 47.3 & 1793.0 & 3790.7 & 9.40 & 16.9 & 35.6 & 564 & 1.01 & 2.14 \\
\hline Shaanxi & 55.7 & 1129.9 & 2028.5 & 6.43 & 7.27 & 13.0 & 443 & 0.500 & 0.898 \\
\hline Inner Mongolia & 15 & 422.5 & 2816.6 & 6.79 & 2.87 & 19.1 & 458 & 0.193 & 1.29 \\
\hline Liaoning & 31.1 & 682.7 & 2195.2 & 9.30 & 6.35 & 20.4 & 717 & 0.490 & 1.57 \\
\hline Jilin & 15 & 566.0 & 3773.1 & 9.11 & 5.16 & 34.4 & 709 & 0.401 & 2.68 \\
\hline Heilongjiang & 35.1 & 1506.7 & 4292.7 & 5.22 & 7.87 & 22.4 & 552 & 0.831 & 2.37 \\
\hline Shanghai & 47.8 & 47.6 & 99.60 & 6.80 & 0.324 & 0.677 & 671 & 0.0319 & 0.0668 \\
\hline Jiangsu & 31.9 & 822.6 & 2578.6 & 8.15 & 6.70 & 21.0 & 730 & 0.600 & 1.88 \\
\hline Zhejiang & 23.9 & 197.6 & 826.9 & 5.74 & 1.13 & 4.74 & 625 & 0.123 & 0.516 \\
\hline Anhui & 30.3 & 914.5 & 3018.2 & 6.62 & 6.06 & 20.0 & 663 & 0.607 & 2.00 \\
\hline Fujian & 35.5 & 203.9 & 574.3 & 6.15 & 1.25 & 3.53 & 643 & 0.131 & 0.369 \\
\hline Jiangxi & 65.1 & 1062.0 & 1631.3 & 5.30 & 5.63 & 8.64 & 606 & 0.643 & 0.988 \\
\hline Shandong & 23.6 & 937.5 & 3972.5 & 12.6 & 11.8 & 50.1 & 694 & 0.650 & 2.76 \\
\hline Henan & 34.6 & 1577.8 & 4560.2 & 10.6 & 16.6 & 48.1 & 610 & 0.963 & 2.78 \\
\hline Hubei & 38 & 724.4 & 1906.4 & 7.33 & 5.31 & 14.0 & 694 & 0.503 & 1.32 \\
\hline Hunan & 20 & 387.2 & 1935.8 & 8.11 & 3.14 & 15.7 & 728 & 0.282 & 1.41 \\
\hline Guangdong & 41.4 & 630.3 & 1522.4 & 5.50 & 3.47 & 8.38 & 614 & 0.387 & 0.935 \\
\hline Guangxi & 15 & 305.3 & 2035.6 & 5.26 & 1.61 & 10.7 & 604 & 0.184 & 1.23 \\
\hline Hainan & 38 & 115.9 & 305.1 & 3.33 & 0.386 & 1.02 & 520 & 0.0603 & 0.159 \\
\hline Chongqing & 15 & 173.5 & 1156.7 & 7.25 & 1.26 & 8.38 & 690 & 0.120 & 0.798 \\
\hline Sichuan & 14.3 & 456.3 & 3190.7 & 7.94 & 3.62 & 25.3 & 720 & 0.329 & 2.30 \\
\hline Guihzou & 15 & 298.6 & 1990.4 & 5.16 & 1.54 & 10.3 & 600 & 0.179 & 1.19 \\
\hline Yunnan & 15 & 448.1 & 2987.0 & 4.57 & 2.05 & 13.6 & 574 & 0.257 & 1.71 \\
\hline Tibet & 15 & 10.8 & 72.1 & 5.64 & 0.0611 & 0.407 & 621 & 0.00672 & 0.0448 \\
\hline Shaanxi & 32 & 941.4 & 2941.9 & 4.53 & 4.27 & 13.3 & 108 & 0.102 & 0.318 \\
\hline Gansu & 26.8 & 541.7 & 2021.3 & 4.27 & 2.31 & 8.63 & 104 & 0.0561 & 0.209 \\
\hline Qinghai & 15 & 23.7 & 157.7 & 3.19 & 0.0754 & 0.503 & 85.1 & 0.00201 & 0.0134 \\
\hline Ningxia & 7 & 42.6 & 609.2 & 6.01 & 0.256 & 3.66 & 133 & 0.00569 & 0.0812 \\
\hline Xinjiang & 15 & 202.4 & 1349.2 & 8.42 & 1.70 & 11.4 & 175 & 0.0353 & 0.236 \\
\hline Total & & 1722 & 60669 & & 128 & 450 & & 9.76 & 34.4 \\
\hline
\end{tabular}

The data of Hong Kong Special Administrative Region, Macao Special Administrative Region and Taiwan Province were not included.

The potential scenario was set according to the technical feasibility for straw return. In the potential scenario of straw return, the amount of straw returned in each province is equal to $\mathrm{ST}_{i}$ (Table 2).

In the current scenario, straw return was popularized in less area of croplands. The PI of different provinces in China varied from 7\% to $67.1 \%$ (Gao et al., 2000; Li, 2003; Yang et al., 2003; Zhong et al., 2003; Weng et al., 2004; Han et al., 2005). Quite a large percentage of the straw was burnt, and some served as fuel, feed or industrial material.

NT. For the current scenario, the area of NT was set based on the NT implementation data in 2002
(Editing Committee of China Agricultural Machinery Yearbook, 2003).

For the potential scenario, the area of NT was set according to a national plan for extension of conservative tillage. Conservative tillage would be implemented in $20 \%$ of the cropland in 13 provinces, autonomous regions and municipalities (Beijing, Tianjin, Hebei, Shanxi, Inner Mongolia, Liaoning, Jilin, Heilongjiang, Shaanxi, Gansu, Ningxia, Qinghai, Xinjiang) in the northern part of China. In other parts of China, NT would be implemented on $10 \%$ of the cropland as a money and energy-saving practice. 


\section{Results}

\section{Nitrogen fertilizer application}

Although SCSR was influenced by many factors, such as fertilization, climate, soil characteristics and crop practices, significant linear relationship was derived from experimental data for each of the four agricultural regions (Fig. 2). The slopes of these equations were found lowest in North China (0.5286), which meant lower SOC accumulation in North China induced by increasing nitrogen fertilizer.

In the current situation, $12.07 \mathrm{Mt}$ of nitrogen fertilizer was applied to rice, wheat and maize in China each year (Table 3). In the eastern part of South China, the rate was generally higher because there were more crops a year, so more fertilizer was required. The carbon sequestration amounted to $5.96 \mathrm{TgC} \mathrm{yr}^{-1}$ (Table 3). The highest sequestration found in the southeast part of China was more than $300 \mathrm{kgCha}^{-1}$.

According to experts' recommendations, fertilizer application can be increased to $16.9 \mathrm{Mt} \mathrm{yr}^{-1}$. Under this condition, the carbon sequestration potential will be 12.1 $\mathrm{TgC} \mathrm{yr}^{-1}$ (Table 3). The increase in the carbon sequestration potential is remarkable in South China and Northeast China.

\section{Straw return}

Derived from the long-term experimental data, significant linear relationships between SCSR and the amount of returned straw were established for each of the four agricultural regions (Fig. 3). In South China, the regression coefficient was low because the data were distributed dispersedly (Fig. 3). The slope of the regression equation in Northwest China was obviously lower than that in the other regions (Fig. 3).

The density of air-dried straw returned varied from 3.19 to $12.6 \mathrm{t} \mathrm{ha}^{-1} \mathrm{yr}^{-1}$ (Table 2). The regions with higher density were located in the eastern part of China, especially in the three plains: Song-Nen Plain, HuangHuai-Hai Plain and plain of middle and low reaches of Yangtze River (Table 2).

In the current situation, the total straw returned to croplands was $128 \mathrm{Tg} \mathrm{yr}^{-1}$ (Table 2). The activity concentrated in regions of North China, such as Hebei, Shandong and Henan Provinces. The average PI of this region was over $40 \%$ (Table 2), higher than that of the other three

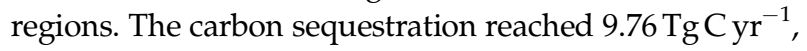
mainly in South and North China (Table 2).

In China, the potential amount of straw to be returned will reach $450 \mathrm{Tg} \mathrm{yr}^{-1}$ (Table 2), an increase of 2.5 times as compared with that in the current situation. The corresponding carbon sequestration will arrive at $34.4 \mathrm{TgC}^{-1}{ }^{-1}$, which is $253 \%$ over the current value. The higher potential amount of straw return and its induced carbon sequestration potential are located in South China and North China (Table 2).

\section{NT}

From the limited data available, we could also see that the carbon sequestration rate in Northwest China was the highest and that in North China was the lowest (Table 4).

In the current situation, NT was implemented in 4.12 Mha of croplands, which was concentrated in the eastern part of China, such as Heilongjiang, Hebei, Henan, Jiangsu and Anhui Provinces. The carbon
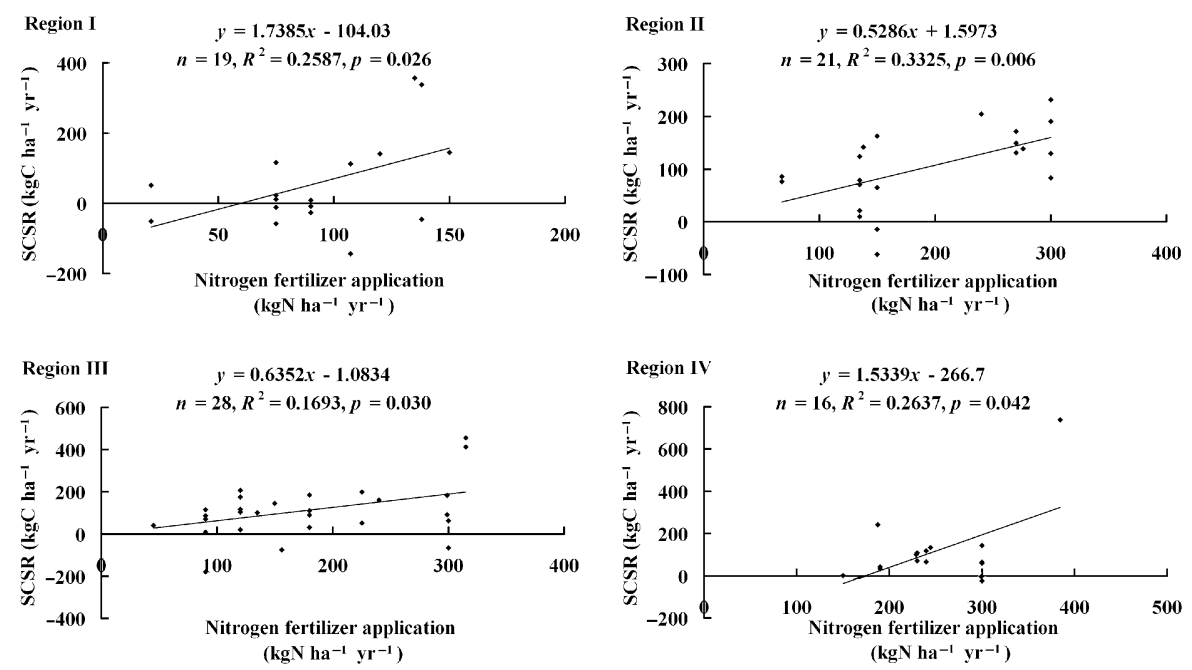

Fig. 2 Relationships between the soil carbon sequestration rate (SCSR) and the amount of nitrogen fertilizer applied.

(C) 2008 The Authors

Journal compilation (C) 2008 Blackwell Publishing Ltd, Global Change Biology, 15, 281-305 
Table 3 Nitrogen fertilizer application and its carbon sequestration in soil

\begin{tabular}{|c|c|c|c|c|c|c|c|c|c|}
\hline \multirow[b]{2}{*}{ Province } & \multirow[b]{2}{*}{$A_{i}\left(10^{3}\right.$ ha $)$} & \multicolumn{2}{|c|}{$\begin{array}{l}\text { Nitrogen fertilizer } \\
\text { applied }\left(10^{3} \mathrm{tyr}^{-1}\right)\end{array}$} & \multicolumn{2}{|c|}{$\begin{array}{l}\text { Nitrogen applied } \\
\text { to unit area of } \\
\text { cropland } \\
\left(\mathrm{kgN} \mathrm{ha}^{-1} \mathrm{yr}^{-1}\right)\end{array}$} & \multicolumn{2}{|c|}{$\begin{array}{l}\text { Soil carbon } \\
\text { sequestration } \\
\text { rates } \\
\left(\mathrm{kgCha}^{-1} \mathrm{yr}^{-1}\right)\end{array}$} & \multicolumn{2}{|c|}{$\begin{array}{l}\text { Soil carbon } \\
\text { sequestration } \\
\left(\mathrm{TgC} \mathrm{yr}^{-1}\right)\end{array}$} \\
\hline & & Current & Potential & Current & Potential & Current & Potential & Current & Potential \\
\hline Beijing & 125.3 & 33.2 & 27.2 & 265 & 217 & 142 & 116 & 0.0177 & 0.0146 \\
\hline Tianjin & 203.5 & 45.5 & 50.4 & 224 & 248 & 120 & 132 & 0.0244 & 0.0270 \\
\hline Hebei & 3790.7 & 928 & 1133 & 245 & 299 & 131 & 160 & 0.497 & 0.605 \\
\hline Shaanxi & 2028.5 & 209 & 392 & 103 & 193 & 56.1 & 104 & 0.114 & 0.210 \\
\hline Inner Mongolia & 2816.6 & 196 & 484 & 69 & 172 & 38.3 & 92.5 & 0.108 & 0.260 \\
\hline Liaoning & 2195.2 & 378 & 476 & 172 & 217 & 195 & 273 & 0.429 & 0.599 \\
\hline Jilin & 3773.1 & 510 & 784 & 135 & 208 & 131 & 257 & 0.494 & 0.970 \\
\hline Heilongjiang & 4292.7 & 220 & 856 & 51 & 199 & -14.9 & 242 & -0.0640 & 1.04 \\
\hline Shanghai & 99.6 & 34.5 & 29.9 & 347 & 300 & 265 & 194 & 0.0264 & 0.0193 \\
\hline Jiangsu & 2578.6 & 1061 & 892 & 412 & 346 & 364 & 264 & 0.940 & 0.680 \\
\hline Zhejiang & 826.9 & 229 & 249 & 277 & 302 & 158 & 196 & 0.131 & 0.162 \\
\hline Anhui & 3018.2 & 738 & 1053 & 245 & 349 & 108 & 269 & 0.328 & 0.811 \\
\hline Fujian & 574.3 & 240 & 228 & 418 & 397 & 375 & 342 & 0.215 & 0.196 \\
\hline Jiangxi & 1631.3 & 284 & 613 & 174 & 376 & 0.0210 & 310 & $3.43 \mathrm{E}-05$ & 0.506 \\
\hline Shandong & 3972.5 & 1180 & 1325 & 297 & 334 & 159 & 178 & 0.630 & 0.707 \\
\hline Henan & 4560.2 & 1390 & 1791 & 305 & 393 & 163 & 209 & 0.742 & 0.954 \\
\hline Hubei & 1906.4 & 586 & 627 & 307 & 329 & 205 & 238 & 0.390 & 0.454 \\
\hline Hunan & 1935.8 & 531 & 859 & 274 & 444 & 154 & 414 & 0.298 & 0.801 \\
\hline Guangdong & 1522.4 & 515 & 515 & 338 & 338 & 252 & 252 & 0.384 & 0.383 \\
\hline Guangxi & 2035.6 & 348 & 666 & 171 & 327 & -4.28 & 235 & -0.00871 & 0.478 \\
\hline Hainan & 305.1 & 65.4 & 82.2 & 214 & 269 & 62.2 & 146 & 0.0190 & 0.0447 \\
\hline Chongqing & 1156.7 & 211 & 356 & 182 & 307 & 12.5 & 205 & 0.0145 & 0.237 \\
\hline Sichuan & 3190.7 & 620 & 1046 & 194 & 328 & 31.4 & 236 & 0.100 & 0.754 \\
\hline Guihzou & 1990.4 & 199 & 440 & 100 & 221 & -113 & 72.7 & -0.225 & 0.145 \\
\hline Yunnan & 2987.0 & 378 & 629 & 127 & 211 & -72.4 & 56.4 & -0.216 & 0.168 \\
\hline Tibet & 72.1 & 3.90 & 10.5 & 54 & 146 & -185 & -42.5 & -0.0133 & -0.00307 \\
\hline Shaanxi & 2941.9 & 514 & 546 & 175 & 186 & 110 & 117 & 0.323 & 0.344 \\
\hline Gansu & 2021.3 & 158 & 340 & 78 & 168 & 48.5 & 106 & 0.0980 & 0.214 \\
\hline Qinghai & 157.7 & 8.40 & 24.1 & 53 & 153 & 32.8 & 95.9 & 0.00517 & 0.0151 \\
\hline Ningxia & 609.2 & 77.9 & 126 & 128 & 208 & 80.1 & 131 & 0.0488 & 0.0796 \\
\hline Xinjiang & 1349.2 & 173 & 281 & 128 & 208 & 80.4 & 131 & 0.108 & 0.177 \\
\hline Total & 60668.7 & 12067 & 16931 & & & & & 5.96 & 12.1 \\
\hline
\end{tabular}

The data of Hong Kong Special Administrative Region, Macao Special Administrative Region and Taiwan Province were not included.

sequestration was $0.800 \mathrm{TgC} \mathrm{yr}^{-1}$ (Table 5). Under the potential situation, the implementation area of NT would reach $20.40 \mathrm{Mha}$, and the carbon sequestration potential would be $4.60 \mathrm{TgC}^{-1}$ (Table 5).

\section{Discussions}

\section{SCS}

Soil as an important carbon pool plays an essential role in influencing the atmospheric $\mathrm{CO}_{2}$. A large quantity of soil carbon has been released from soil in the human history, mainly due to cultivation for crop production.
In the past 150 years, the soil carbon loss from China's cropland was 5.86 PgC (Houghton, 2002). The soil carbon loss is still continuing in agricultural lands. How to reverse the cropland soils from a carbon source to a carbon sink is very important for mitigating global warming caused by the rise of $\mathrm{CO}_{2}$ in the atmosphere.

The amount of SOC is determined by the balance between inputs of organic detritus and losses through decomposition, leaching to groundwater and erosion (Post et al., 2004; Lal, 2001). Any agricultural activity that increases the input or reduces the loss can be a measure to sequester atmospheric carbon (Lal, $2004 a, b)$. For example, increase in crop biomass and 

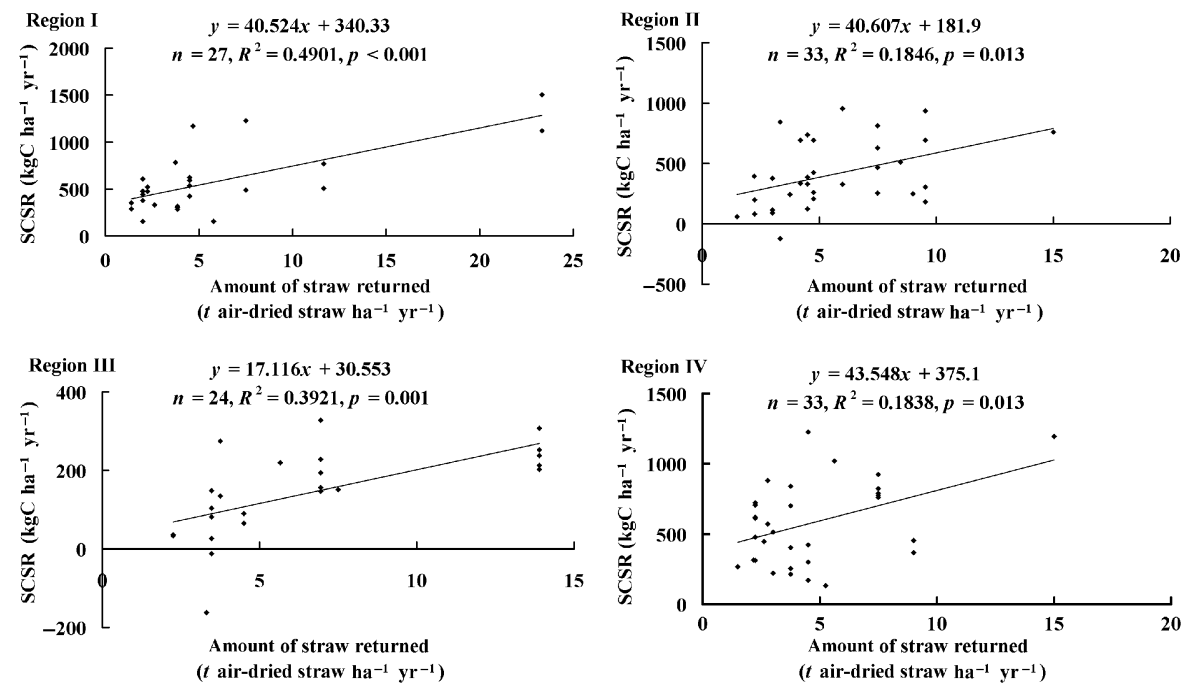

Fig. 3 Relationships between the soil carbon sequestration rate (SCSR) and the amount of straw returned.

Table 4 Soil carbon sequestration rate by no-tillage

\begin{tabular}{llll}
\hline & & \multicolumn{2}{l}{$\begin{array}{l}\text { Soil carbon sequestration } \\
\text { rate }\left(\mathrm{kgC} \mathrm{ha}^{-1} \mathrm{yr}^{-1}\right)\end{array}$} \\
\cline { 3 - 4 } $\begin{array}{l}\text { Agricultural } \\
\text { region }\end{array}$ & $\begin{array}{l}\text { Pairs of } \\
\text { data }\end{array}$ & Mean & Standard deviation \\
\hline I & 1 & 255 & - \\
II & 5 & 157 & 52.8 \\
III & 1 & 390 & - \\
IV & 12 & 198 & 154 \\
\hline
\end{tabular}

straw return will increase soil carbon input, and NT reduces the disturbance to soil and thereby the carbon loss. This has been proved by numbers of long-term field experiments in the USA and Europe as well as in China.

For estimating SCS, it is crucial and always difficult to obtain the SCS rate for each practice, because the rate varies with the sites under study. After the review of the long-term field experiments in China, significant linear relationships between SCS and the amount of fertilizer applied and straw returned were found to get the carbon sequestration rates for each agricultural region. In our study, the estimation of carbon sequestration of nitrogen fertilizer application and straw return was based on the statistical consistency in each agricultural region. Carbon sequestration rates for NT were calculated simply by averaging the available experimental data for each agricultural region.

The completeness of agricultural practices changes with social, economic and technical development. For instance, 10 years ago in China, straw was harvested for meeting the shortages in fuel for cooking and heating and in forage for feeding livestock. Less straw return is an important factor causing soil carbon loss in China. Li et al. (2003) concluded that the cropland soil lost $1.6 \%$ of SOC, because less (only 25\%) aboveground residue was returned. With the enhancement of the rural living standard and the expanded use of coal and electric power, straw is now usually burned in the fields for timely sowing of the next crop because of lacking in proper handling machines. Compared with synthetic fertilizer application, straw return requires more machine use and may lead to additional economic cost. Concluded from the available reports in China, only $7-65.1 \%$ of the straw was returned in croplands with a large regional variance (Table 2). NT was extended to 4118.8 kha of cropland, which only accounted for $3 \%$ of the cropland area in China. The amount of fertilizer application was relatively high, and the national average was $199 \mathrm{~kg} \mathrm{ha}^{-1}$ (Table 3), with the highest of more than $400 \mathrm{~kg} \mathrm{ha}^{-1}$ in Jiangsu and Fujian (Table 3). However, application of nitrogen fertilizer was still not sufficient to meet the need of crop production in some provinces.

Compared with straw return and nitrogen fertilizer application, the carbon sequestration potential of NT was relatively small. In our study, according to the setting of the potential scenario, the cropland area of NT only accounted for $16 \%$ of China's cropland (Editorial Board of China Agricultural Yearbook, 2005). In China, besides the systematic technology of conservation tillage popularized by the government, NT was promoted as a money and energy-saving technique. Because of the decentralization of farmers and agricul- 
Table 5 No-tillage and its carbon sequestration in soil

\begin{tabular}{|c|c|c|c|c|}
\hline \multirow[b]{2}{*}{ Province } & \multicolumn{2}{|c|}{$\begin{array}{l}\text { No-tillage } \\
\text { extended } \\
\left(10^{3} \text { ha yr }^{-1}\right)\end{array}$} & \multicolumn{2}{|c|}{ 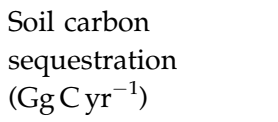 } \\
\hline & Current & Potential & Current & Potentia \\
\hline Beijing & 34.8 & 68.8 & 5.45 & 10.8 \\
\hline Tianjin & 38.6 & 97.1 & 6.04 & 15.2 \\
\hline Hebei & 1483.2 & 1376.7 & 232 & 216 \\
\hline Shaanxi & 73.6 & 917.7 & 11.5 & 144 \\
\hline Inner Mongolia & 164.7 & 1640.2 & 25.8 & 257 \\
\hline Liaoning & 5.5 & 835.0 & 1.39 & 213 \\
\hline Jilin & 80.8 & 1115.7 & 20.6 & 285 \\
\hline Heilongjiang & 425.7 & 2354.6 & 109 & 601 \\
\hline Shanghai & 16.8 & 31.5 & 3.32 & 6.24 \\
\hline Jiangsu & 742.5 & 506.2 & 147 & 100 \\
\hline Zhejiang & 5.2 & 212.5 & 1.04 & 42.1 \\
\hline Anhui & 161.3 & 597.2 & 31.9 & 118 \\
\hline Fujian & 0.0 & 143.5 & 0.00594 & 28.4 \\
\hline Jiangxi & 4.0 & 299.3 & 0.792 & 59.2 \\
\hline Shandong & 76.3 & 1537.9 & 12.0 & 241 \\
\hline Henan & 485.1 & 1622.1 & 76.0 & 254 \\
\hline Hubei & 4.5 & 495.0 & 0.883 & 98.0 \\
\hline Hunan & 2.3 & 395.3 & 0.445 & 78.2 \\
\hline Guangdong & 0.0 & 327.2 & 0 & 64.8 \\
\hline Guangxi & 0.0 & 440.8 & 0 & 87.2 \\
\hline Hainan & 0.0 & 76.2 & 0 & 15.1 \\
\hline Chongqing & 0.0 & 254.5 & 0 & 50.4 \\
\hline Sichuan & 36.4 & 662.4 & 7.20 & 131 \\
\hline Guihzou & 0.1 & 490.4 & 0.0119 & 97.0 \\
\hline Yunnan & 0.2 & 642.2 & 0.0435 & 127 \\
\hline Tibet & 0.0 & 36.3 & 0 & 7.18 \\
\hline Shaanxi & 247.1 & 1028.1 & 96.3 & 401 \\
\hline Gansu & 4.0 & 1004.9 & 1.57 & 392 \\
\hline Qinghai & 4.1 & 137.6 & 1.61 & 53.6 \\
\hline Ningxia & 0.0 & 253.8 & 0.00390 & 98.9 \\
\hline Xinjiang & 22.1 & 797.1 & 8.60 & 311 \\
\hline Total & 4118.8 & 20397.5 & 800 & 4602 \\
\hline
\end{tabular}

The data of Hong Kong Special Administrative Region, Macao Special Administrative Region and Taiwan Province were not included.

tural machine drivers and owners, the implementation area of NT might be underestimated.

Investigations into soil carbon changes and sequestration in China's cropland resulted in different conclusions (Table 6). In the current situation, estimations with models showed that the cropland soil in China was a carbon source (Li et al., 2003; Tang et al., 2006), while field data reviews certified the cropland in China as a carbon sink (Pan et al., 2003; Huang \& Sun, 2006). Li et al. (2003) used DNDC model for estimation of the cropland soil carbon loss, and got the result of $95 \mathrm{TgC} \mathrm{yr}^{-1}$ with a large variation from -29 to
$220 \mathrm{TgC}^{-1}$. The study was based on the database including the cropland area and agricultural practice information in 1990 and the soil organic data digitized from the soil organic matter map published in 1986. This result has also been widely debated by many soil experts in China who reported soil carbon accumulation in many parts of China, especially in paddy soils (Pan et al., 2003). After collecting the data of field surveys on soil carbon changes from the 1980s to the 1990s, Huang \& Sun (2006) estimated that organic carbon increased by 311.3-401.4 $\mathrm{TgC}$ in the surface soil of the cropland in China's mainland in the past 20 years. They postulated that the major factors leading to this increase were increased fertilizer use, popularization of straw return technologies, zero or reduced tillage and manure use. Tang et al. (2006) demonstrated by DNDC model that carbon loss would be increased if no fertilizer and manure were applied in China's cropland. In our estimates, with the current agricultural practices, the carbon sequestration rates were averaged to be $98.2 \mathrm{kgCha}^{-1}$ for nitrogen fertilizer application, $564 \mathrm{kgCha}^{-1}$ for straw return and $157-390 \mathrm{kgC} \mathrm{ha}^{-1}$ for NT. The current carbon sequestration of nitrogen fertilizer application, straw return and NT was 5.96, 9.76 and $0.800 \mathrm{TgC} \mathrm{yr}^{-1}$. The summation of the carbon sequestration measures was $16.5 \mathrm{TgC} \mathrm{yr}^{-1}$. The result of our estimation was very close to Huang \& Sun (2006)'s (15.57-20.07 Tg C $\left.\mathrm{yr}^{-1}\right)$, and tallied with Huang et al.'s conclusion that the increase in SOC in China's cropland was generally contributed by the adoption of the carbon sequestration measures, such as nitrogen fertilizer application, straw return and NT.

Estimated by DNDC, GLO-PEM and CEVSA coupled model, the SCS potentials are significant, varying with the different scenarios assumed (Zhang et al., 2006; Yan et al., 2007). Taking into account the popularization and development of relative techniques and some experts' recommendations, we set the potential scenarios for cropland SCS, with the average fertilizer application at $279 \mathrm{~kg} \mathrm{ha}^{-1}$, straw of rice, wheat and maize fully returned to croplands, and $16 \%$ of the cropland in NT practice. At this level, the SCS of nitrogen fertilizer application, straw return and NT will reach 12.1, 34.4 and $4.60 \mathrm{TgC} \mathrm{yr}^{-1}$, respectively. If the three carbon sequestration measures are popularized as much as that for the potential scenarios, the carbon sequestration potentials can be raised by $102 \%, 253 \%$ and $475 \%$.

Among the three measures, straw return provides the greatest carbon sequestration in both current and potential scenarios. It can sequester $1.5 \%$, in the current situation, and $5.3 \%$, after full popularization, of the annual carbon emission from fossil fuel use in China in the year 1990 (654.7 TgC; Marland et al., 2006). Furthermore, popularization of returning the straw of 
Table 6 Soil carbon changes investigated in China

\begin{tabular}{|c|c|c|c|c|c|}
\hline Number & Methods & Situation & Region concerned & $\begin{array}{l}\text { Soil Carbon } \\
\text { change }\left(\mathrm{TgC}_{\mathrm{yr}}^{-1}\right)\end{array}$ & Reference \\
\hline 1 & DNDC model & 1990 baseline & Whole China & -95 & Li et al. (2003) \\
\hline \multirow[t]{5}{*}{2} & \multirow[t]{5}{*}{ DNDC model } & 1990 baseline & Whole China & -78.89 & \multirow[t]{5}{*}{ Tang et al. (2006) } \\
\hline & & $50 \%$ straw returned & Whole China & -24.3 & \\
\hline & & No-tillage & Whole China & 41.4 & \\
\hline & & No fertilizer & Whole China & -93.6 & \\
\hline & & No manure & Whole China & -101.3 & \\
\hline 3 & $\begin{array}{l}\text { County-based data } \\
\text { review from } \\
\text { literatures }\end{array}$ & Baseline & Whole China & 15.57-20.07 & Huang \& Sun (2006) \\
\hline 4 & $\begin{array}{l}\text { GLO-PEM and } \\
\text { CEVSA coupled } \\
\text { model }\end{array}$ & $\begin{array}{l}50 \% \text { no-tillage and } \\
50 \% \text { straw returned }\end{array}$ & Whole China & 35.2 & Yan et al. (2007) \\
\hline \multirow[t]{2}{*}{5} & \multirow[t]{2}{*}{ Data analysis } & Erosion & Whole China & $-32-64$ & \multirow[t]{2}{*}{ Lal (2002) } \\
\hline & & Desertification & Whole China & -54 & \\
\hline \multirow[t]{2}{*}{6} & \multirow[t]{2}{*}{ Soil survey data } & Paddy soil at present & Whole China & 12 & \multirow[t]{2}{*}{ Pan et al. (2003) } \\
\hline & & Potential & Whole China & 675-2968 (total) & \\
\hline \multirow[t]{3}{*}{7} & \multirow[t]{3}{*}{ DNDC model } & 2000 & Northwestern China & -0.5 & \multirow[t]{3}{*}{ Zhang et al. (2006) } \\
\hline & & $50-59 \%$ of straw returned & Northwestern China & $0.7-2.1$ & \\
\hline & & Manure application & Northwestern China & 0.2 & \\
\hline \multirow[t]{3}{*}{8} & \multirow{3}{*}{$\begin{array}{l}\text { Long-term field } \\
\text { experimental data }\end{array}$} & Fertilizer & Whole China & 5.96 & \multirow[t]{3}{*}{ This study } \\
\hline & & Straw return & Whole China & 9.76 & \\
\hline & & No-tillage & Whole China & 0.800 & \\
\hline
\end{tabular}

DNDC, Denitrification/Decomposition; GLO-PEM, Global Production Efficiency Model; CEVSA, Carbon Exchange between Vegetation, Soil and Atmosphere.

the three cereal crops can enlarge the SCS potential by $24.7 \mathrm{TgC} \mathrm{yr}^{-1}$, which is equal to $2.2 \%$ of the annual carbon emission from fossil fuel use in China in 2003

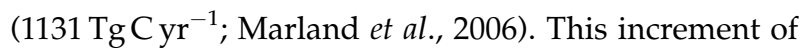
sequestration is four times that of nitrogen fertilizer application and 6.5 times as compared with NT. From the 1980s, due to the rise of crop yield, the amount of straw increased significantly. In order to sow the next crop timely and save them the trouble of handling, many farmers burn straw in the fields. Straw burning, which leads to environmental pollutions, traffic accidents and fires, has turned to a serious social-environmental problem. The Chinese government makes efforts to prohibit straw burning. However, burning straw is still a common practice in the rural areas of many provinces (Cao et al., 2007). Straw return can not only resolve the problem caused by straw burning but also sequester huge amount of carbon. So, straw return is the most promising measure for SCS in China's cropland.

\section{Uncertainties in estimation}

For national or global SCS potentials, it is very difficult to get the accurate estimate because of the large variation in climate, soil characteristics and agricultural practices. So, uncertainty assessment is very important for policy makers, because they should be well aware of the risks in promoting the carbon sequestration measures. In this study, carbon sequestration was determined simply by the carbon sequestration rate and the extent of the agricultural practices. Therefore, the method and data source for obtaining the carbon sequestration rate and the extent of the agricultural practices are very critical.

In this study, the method for estimating the SCS rates of nitrogen fertilizer application and straw return was based on the linear relationship between the rate and the quantities of the fertilizer applied and the straw returned. The best explanation by this linear relationship was $57.7 \%$ for nitrogen fertilizer application and $70 \%$ (Figs 2 and 3) for straw return, respectively. The worst was $41.2 \%$ for nitrogen fertilizer application and $42.9 \%$ for straw return (Figs 2 and 3). SCS rates for NT were estimated by averaging experimental reports for each agricultural region based on 1-12 pairs of data. So, the uncertainty might be large.

Some uncertainties are due to the limited number of the field experimental sites and data. Compared with the large cropland area, there are only a few long-term experimental data available for estimation of the SCS 
rates. For NT, there are only 19 pairs of data for the whole country that has $4.1 \mathrm{Mha}$ of cropland in this practice. For nitrogen fertilizer application and straw return, the data are not available for some provinces and autonomous regions such as Tibet, Guizhou, Qinghai, Guangxi, Anhui, Inner Mongolia, etc. Compared with the USA and Europe where some field experiments have lasted for more than a hundred years, the period of field experiments in China is relatively short. Further efforts are also required in standardized and long-term experiments.

All the 220 pairs of long-term experimental data are cited from peer-reviewed journals on agricultural science, soil, plants and nutrition. In order to get accurate results and reduce errors, great efforts were made to collect and examine these data. The experimental data were strictly screened out in accordance with the following criterion: (1) the duration of the experiment was longer than 3 years; (2) the experiment was systematically designed and with a controlled treatment of no carbon sequestration; (3) all the treatments of the experiments, i.e. the amount of nitrogen fertilization, the amount of straw return and the tillage, were clearly described; and (4) the climate, soil, cropping system and the treatments of the experiments were representative for the regional agriculture. In this study, China's cropland was plotted into four agricultural regions based on the availability of the experimental data. However, there were still some differences in the climate, soil texture, nutrition conditions and some other agricultural factors in each region. In addition, the difference of the interannual dynamics of the above factors would also lead to variation among the longterm experiments.

Extrapolation will possibly lead to errors in our estimation. For straw return, the difference between the current and potential scenarios lay in the area of croplands where straw was returned. The amount of straw returned to each hectare of croplands in each province $\left(S_{i}\right)$ kept steady in the scenarios. In this study, none of the $S_{i}$ exceeded the range of the experimental treatments. As a result, no statistical extrapolation happened in the estimation of the SCS of straw return. For nitrogen fertilizer application, the maximum amount of fertilizer application in the experiments was $150 \mathrm{~kg} \mathrm{Nha}^{-1} \mathrm{yr}^{-1}$ in Region I, $300 \mathrm{~kg} \mathrm{Nha}^{-1} \mathrm{yr}^{-1}$ in Region II and $384.6 \mathrm{~kg} \mathrm{~N}^{-1} \mathrm{yr}^{-1}$ in Region IV (Table A1). The amount of nitrogen fertilizer application to each hectare of croplands in some provinces (Liaoning, Henan, Jiangsu, Fujian in the current situation and Liaoning, Jilin, Heilingjiang, Shangdong, Henan, Fujian, Hunan in the potential scenario) exceeded the range of the experimental treatments (Table 3 ). When the maximum value of the treatments in the experimental data, instead of the values from the scenarios setting, was taken as the amount of nitrogen application to the unit area of croplands in these provinces, the national total carbon sequestration potential of nitrogen fertilizer application decreased by $3.90 \%\left(0.232 \mathrm{TgC}^{-1}\right)$ in the current situation and $12.3 \%\left(1.48{\left.\mathrm{TgC} \mathrm{yr}^{-1}\right)}^{-1}\right.$ in the potential scenario. The possible overestimation caused by extrapolation would be limited in these ranges.

In this study, some uncertainties are in the two scenarios we assumed. In the current scenario, settings for nitrogen fertilizer application and NT were more reliable because there were official statistics for each province. For straw return, because there were no statistics for each province, we had to take experts' experiential values for the percentage of the cropland where straw return techniques were popularized (i.e. the PI). For the potential scenario, the uncertainty in estimation came from the uncertainties of the current scenario on one hand, and on the other hand from the assumption we made about the future social and economic development, and even the future carbon market. Uncertainty could also come from settings of nitrogen fertilizer application and straw return scenarios. With the experimental data available, we only estimated the carbon sequestration of the cropland where the three major cereal crops, i.e. rice, wheat and maize, were planted. This part of the cropland only accounted for $46.6 \%$ of China's total cropland area and received less than $50 \%$ of the national total amount of synthetic nitrogen application (national total of $\mathrm{FC}_{i}$ ). Furthermore, straw of some other crops, such as sorghum, cotton, sugarcane and potato, is also returned to cropland in China, which may also contribute to the SCS potential. Another source of uncertainty came from the value of SGR. The SGR of paddy rice in this study was 0.623 , which was much lower than the result given by Zhang \& Zhu (1990) (1.32-1.43). However, Zhang \& Zhu's value was from samples taken in early years of the 1980s (1981-1984). In the later years, the Chinese government strengthened the popularization of newly developed varieties of hybrid rice with high yield and low SGR, and hybrid rice varieties have got the dominating position in China's rice production (Mao et al., 2006). In this situation, the value we took in this study (0.623) was better to reflect the straw amount of China's paddy rice.

\section{Soil carbon saturation}

The soil carbon stocks cannot be increased without limit. There are several lines of evidence that suggest the existence of a carbon saturation level based on physiochemical processes that stabilize or protect organic compounds in soils (Six et al., 2002). Therefore, 
carbon sequestration in soils does not represent a 'permanent' solution of mitigation (Hutchinson et al., 2007). After a new equilibrium or 'a new steady state' (West $\&$ Six, 2007) is reached and no further change takes place, carbon cannot be sequestrated in soil any more. However, SCS in cropland soils could still be a 'buytime' mitigation measure, which provides part of a raft of short/medium-term climate mitigation measures implemented to act while other, more permanent, carbon emission reduction technologies (such as non- $\mathrm{CO}_{2-}$ emitting energy sources) are developed (Smith, 2004).

Because China is a large developing country with a huge area of croplands, there are considerable potentials for implementation of carbon sequestration measures, and the carbon pool of the Chinese croplands is not about to get saturated. Among the 31 provinces in China's mainland, 26 provinces still need more nitrogen fertilizer application to get higher crop yields (Table 3 ). Crop residues had long been used for fuel and forage instead of being returned to croplands. Many investigations show that the cropland soil has been accumulating carbon in recent years because of increased residue return (Pan et al., 2003; Huang \& Sun, 2006). There was a sharp increase in the national total area of NT from 1.33 Mha in 1991 (Editing Committee of China Agricultural Machinery Yearbook, 1992) to 4.12 Mha in 2002 , which however only accounted for less than $4 \%$ of China's total area of croplands.

\section{Leakage and other environmental consequences}

Carbon leakage is also a serious problem to be considered in estimation of SCS. Adoption of certain carbon sequestration measures in croplands may lead to additional greenhouse gas emission or fossil fuel use (Smith et al., 2001; Smith, 2004). As fertilizer production releases a large quantity of $\mathrm{CO}_{2}$ from burning fossil fuel, and nitrogen fertilizer application increases soil $\mathrm{N}_{2} \mathrm{O}$ emission, carbon sequestration by fertilizer application in croplands may not compensate for the global warming potential caused by $\mathrm{CO}_{2}$ release during fertilizer production and $\mathrm{N}_{2} \mathrm{O}$ release due to fertilizer application. However, fertilizer application is still necessary for enhancement of the crop yield. Straw return requires machines to have the straw chopped and mixed with soil. Operation of these machines will release $\mathrm{CO}_{2}$. Adoption of NT may save fossil fuel up to $23.8 \mathrm{kgC} \mathrm{ha}^{-1} \mathrm{yr}^{-1}$ as compared with CT (Smith et al., 2004). So, when assessing the potential of a SCS option, it is the full greenhouse gas budget that needs to be considered rather than the impact on soil carbon alone.

In addition, the environmental consequences of the SCS measures should be taken into consideration. For example, straw return and NT are able to help prevent soil and water loss, while nitrogen fertilizer application increases nonpoint nitrogen loss, which is a major cause of lake eutrophication in China (Li et al., 2003).

\section{Conclusions}

Based on the long-term field experimental data and statistical data, we estimated the current and potential SCSs by nitrogen fertilizer application, straw return and NT in China. Although there are many factors that cause some uncertainties in the estimates, we are still very confident that these measures can contribute to sequestration of the atmospheric carbon to such an extent that they are worth our attention. In the current situation, nitrogen fertilizer application, straw return and NT can sequester 5.96, 9.76 and $0.800 \mathrm{TgC}$ each year. Carbon sequestration potential will increase to $12.1 \mathrm{TgC} \mathrm{yr}^{-1}$ if nitrogen is fertilized in accordance with experts' recommendations. The carbon sequestration potentials of straw return and NT can reach 34.4 and $4.60 \mathrm{TgC}^{-1}$ when these two techniques are further popularized.

Among the three measures, straw return owns the greatest carbon sequestration in both current and potential scenarios. Straw return can sequester $1.5 \%$, in the current situation, and $5.3 \%$, after full popularization, of the annual carbon emission from fossil fuel use in China in the year 1990. Furthermore, popularization of returning the straw of cereal crops can enlarge the SCS potential by $24.7 \mathrm{TgC}_{\mathrm{yr}}^{-1}$, which is equal to $2.2 \%$ of the annual carbon emission from fossil fuel use in China in 2003.

China, as a developing country, does not have any commitment under the Kyoto Protocol for limitation and reduction of $\mathrm{CO}_{2}$ emission from fossil fuel combustion for the time being. With the rapid economic development and the energy structure highly depending on coal, China will become the largest $\mathrm{CO}_{2}$ emission country surpassing the USA in future. It has been strongly requested by the peoples both at home and abroad that China should be included in implementing the commitment of $\mathrm{CO}_{2}$ emission limitation and reduction. Raising the carbon storage in terrestrial ecosystems, including cropland soils, may be the first step that China should take, because increasing terrestrial carbon can not only sequester the atmospheric carbon, but also improve ecosystems that have degraded in China for a long period. However, incentive policies and measures need to be elaborated by the government.

\section{Acknowledgements}

This study was supported by the Ministry of Science and Technology (2002CB412503), NSF of China (40321101) and the Chinese Academy of Sciences (KZCX1-Sw-01-17). 


\section{References}

Bellamy PH, Loveland PJ, Bradley RI, Lark RM, Kirk JD (2005) Carbon losses from all soils across England and Wales 19782003. Nature, 437, 245-248.

Cao GL, Zhang XY, Wang YQ, Zheng FC (2007) Estimating the quantity of air pollutant emission due to crop residues burnt in open field in China. Chinese Science Bulletin, 52, 1826-1831 (in Chinese).

Cole CV, Flach K, Lee J, Sauerbeck D, Stewart B (1993) Agricultural sources and sinks of carbon. Water, Air, and Soil Pollution, 70, 111-122.

Dumanski J, Desjardins RL, Tarnocai C, Monreal D, Gregorich EG, Kirkwood V, Campbell CA (1998) Possibilities for future carbon sequestration in Canadian agriculture in relation to included oat and alfalfa in the rotation had the greatest land use changes. Climate Change, 40, 81-103.

Editing Committee of China Agricultural Machinery Yearbook (1992) China Agricultural Machinery Yearbook 1992. Editorial Department of China Agricultural Machinery Yearbook, Beijing, 210 pp. (in Chinese).

Editing Committee of China Agricultural Machinery Yearbook (2003) China Agricultural Machinery Yearbook 2003. Editorial Department of China Agricultural Machinery Yearbook, Beijing, 183 pp. (in Chinese).

Editorial Board of China Agriculture Yearbook (2005) China Agriculture Yearbook 1980-2005, electronic edn. China Agriculture Press, Beijing, China (in Chinese).

FAO Statistics Division (2007) FAO Statistical Yearbook 2005-2006. Available online at http://www.fao.org/statistics/yearbook/ vol_1_1/xls/a04.xls.

Follett RF (2001) Soil management concepts and carbon sequestration in cropland soils. Soil $\mathcal{E}$ Tillage Research, 61, 77-92.

Freibauer A, Rounsevell MD, Smith P, Verhagen J (2004) Carbon sequestration in the agricultural soils of Europe. Geoderma, 122, $1-23$.

Gao XZ, Ma WQ, Ma CB, Zhang FS, Wang YH (2000) Analysis on the current status of utilization of crop straw in China. Journal of Huazhong Agricultural University, 21, 242-247 (in Chinese).

Halvorson AD, Reule CA, Follett RF (1999) Nitrogen fertilization effects on soil carbon and nitrogen in a dryland cropping system. Soil Science Society of America Journal, 63, 912-917.

Han LJ, Yan QJ, Liu XY, Hu JY (2005) Straw resources and their utilization in China. Transactions of the CSAE, 18, 87-91 (in Chinese).

Houghton RA (2002) Temporal patterns of land-use change and carbon storage in China and tropical Asia. Science in China (Series C), 45, 10-17.

Huang Y, Sun WJ (2006) Changes in topsoil organic carbon of croplands in mainland China over the last two decades. Chinese Science Bulletin, 51, 1785-1803.

Hurtt GC, Pacala SW, Moorcroft PR, Caspersen J, Shevliakova E, Houghton RA, Moore B III (2002) Projecting the future of the U.S. carbon sink. Ecology, 99, 1389-1394.

Hutchinson JJ, Campbell CA, Desjardins RL (2007) Some perspectives on carbon sequestration in agriculture. Agricultural and Forest Meteorology, 142, 288-302.
Institute of Soil Science, Chinese Academy of Sciences (2005) Soil Database of China. Available online at http://www.soil.csdb. $\mathrm{cn} / \mathrm{stdc}$.htm (in Chinese).

Intergovernmental Panel on Climate Change (2000) Land Use, Land-Use Change, and Forestry. Cambridge University Press, Cambridge, UK pp. 31-32.

Intergovernmental Panel on Climate Change (2001) Climate Change: Mitigation. Cambridge University Press, Cambridge, UK pp. 324-326.

Janssens IA, Freibauer A, Ciais P et al. (2003) Europe's terrestrial biosphere absorbs $7-12 \%$ of European anthropogenic $\mathrm{CO}_{2}$ emissions. Science, 300, 1538-1542.

Lal R (1997) Residue management, conservation tillage and soil restoration for mitigating greenhouse effect by $\mathrm{CO}_{2}$-enrichment. Soil \& Tillage Research, 43, 81-107.

Lal R (2001) World cropland soils as a source or sink for atmospheric carbon. Advances in Agronomy, 71, 145-191.

Lal R (2002) Soil carbon sequestration in China through agricultural intensification, and restoration of degraded and decertified ecosystems. Land Degradation and Development, 13, 469-478.

Lal R (2004a) Soil carbon sequestration impacts on global climate change and food security. Science, 304, 1623-1626.

Lal R (2004b) Soil carbon sequestration to mitigate climate change. Geoderma, 123, 1-22.

Lal R, Bruce JP (1999) The potential of world cropland soils to sequester $\mathrm{C}$ and mitigate the greenhouse effect. Environmental Science and Policy, 2, 177-185.

Lal R, Kimble JM, Follet RF, Cole CV (1998) The Potential of U.S. Cropland to Sequester Carbon and Mitigate the Greenhouse Effect. Ann Arbor Press, Chelsea, MI, USA.

Li AX (2003) Organic fertilizer utility in current situation and its developing strategy in Hunan Province. Hunan Agricultural Sciences, 2003, 8-10 (in Chinese).

Li CS, Zhuang YH, Frolking S et al. (2003) Modeling soil organic carbon change in croplands of China. Ecological Applications, 13, 327-336.

Li JK, Lin B, Liang GQ, Shen GQ (2001) Dissecting the perspectives of fertilizer application in China. Phosphate $\mathcal{E}$ Compound Fertilizer, 16, 1-5 (in Chinese).

Liu XH, Gao WS, Zhu WS (2001) Mechanism and Techniques of Straw Returning. China Agriculture Press, Beijing, pp. 34-64, 67-114, 124-130, 138-176 (in Chinese).

Lu RK (2004) Phosphorus resources and phosphate fertilizer production and consumption of China. II. Phosphate fertilizer consumption and predicted demand. Soils, 36, 113-116 (in Chinese).

Marland G, Boden TA, Andres RJ (2006) Global, regional, and national $\mathrm{CO}_{2}$ emissions. In: Trends: A Compendium of Data on Global Change. Carbon Dioxide Information Analysis Center, Oak Ridge National Laboratory, U.S. Department of Energy, Oak Ridge, TN, USA. Available at http://cdiac.ornl.gov/ trends/emis/tre_prc.htm.

Mao CX, Wan ZY, Ma GH et al. (2006) Current status analysis of hybrid rice development in China. Hybrid Rice, 21, 1-5 (in Chinese).

MOA/DOE Project Expert Team (1998) Assessment of Biomass Resource Availability in China. China Environmental Science Press, Beijing, 8 pp. (in Chinese). 
Pan G, Li L, Wu L, Zheng X (2003) Storage and sequestration potential of topsoil organic carbon in China's paddy soils. Global Change Biology, 10, 79-92.

Post WM, Izaurralde RC, Jastrow JD et al. (2004) Enhancement of carbon sequestration in US soils. BioScience, 54, 895-908.

Qin XX (2007) Proper amount of nitrogen fertilizer application on seed corn. Information of Agricultural Science and Technology, 2007, 16-17 (in Chinese).

Rasmussen PE, Parton WJ (1994) Long-term effects of residue management in wheat-fallow: I. Inputs, yield, and soil organic matter. Soil Science Society of America Journal, 58, 523-530.

Shen EL, Li JM, Li ZC et al. (2004) New Applied Handbook of Fertilizer. Middle China Farmer Publishing House, Zhengzhou, China, pp. 148-152 (in Chinese).

Six J, Connant RT, Paul EA, Pausian K (2002) Stabilization mechanisms of soil organic matter: implications for C-saturation of soils. Plant and Soil, 241, 155-176.

Smith P (2004) Carbon sequestration in croplands: the potential in Europe and the global context. European Journal of Agronomy, 20, 229-236.

Smith P, Goulding KW, Smith KA, Powlson DS, Smith JU, Falloon PD, Coleman K (2001) Enhancing the carbon sink in European agricultural soils: including trace gas fluxes in estimates of carbon mitigation potential. Nutrient Cycling in Agroecosystems, 60, 237-252.

Smith P, Powlson DS, Glendining MJ, Smith JU (1998) Preliminary estimates of the potential for carbon mitigation in European soils through no-till farming. Global Change Biology, 4, 679-685.

Tan JF, Zhang ZL, Qiu HZ et al. (2003) Principle and Techniques of Fertilization. China Agricultural University Press, Beijing, China, pp. 199-213 (in Chinese).

Tang HJ, Qiu JJ, Ranst EV, Li CS (2006) Estimations of soil organic carbon storage in cropland of China based on DNDC model. Geoderma, 134, 200-206.

The Center for Agricultural Technology Popularization of China. Zeng MX Zhang YJ Shan XZ, Liao CZ (2001) Straw return measures and patterns in major agricultural regions of China. Soils and Fertilizers, 2001, 32-36 (in Chinese).

Weng W, Yang JT, Zhao QL, Zhang BL (2004) Current situation and developing direction of straw utilization technology in China. Integrated Utility of Resources in China, 2004, 18-21 (in Chinese).

West TO, Post WM (2002) Soil organic carbon sequestration rates by tillage and crop rotation: a global data analysis. Soil Science Society of America Journal, 66, 1930-1946.

West TO, Six J (2007) Considering the influence of sequestration duration and carbon saturation on estimates of soil carbon capacity. Climatic Change, 80, 25-41.

Xu XL, Zhang KL, Xu XL, Peng WY (2003) Spatial distribution and estimating of soil organic carbon on Loess Plateau. Journal of Soil and Water Conservation, 17, 13-15 (in Chinese).

Yan H, Cao M, Liu J, Tao B (2007) Potential and sustainability for carbon sequestration with improved soil management in agricultural soils of China. Agriculture, Ecosystems E Environment, 121, 325-335.
Yang XT, Zheng HQ, Wang B (2003) Integrated utility of straw resource in Jilin Province (II). Rural Scientific Experiments, 2003(1), 6 (in Chinese).

Zeng M, Wang R, Peng S et al. (2002) Summary of returning straw into field of main agricultural areas in China. Chinese Journal of Soil Science, 33, 336-339 (in Chinese).

Zhang F, Li C, Wang Z, Wu H (2006) Modeling impacts of management alternatives on soil carbon storage of farmland in Northwest China. Biogeosciences, 3, 451-466.

Zhang FC, Zhu ZH (1990) Harvest index for various crops in China. Scientia Agricultura Sinica, 23, 83-87 (in Chinese).

Zhang QL, Zhang M, Yang YC, Lu JF (2002) Volatilization of ammonium bicarbonate and urea in main soil of Shandong Province. Chinese Journal of Soil Science, 33, 32-34 (in Chinese).

Zhong HP, Yue YZ, Fan JW (2003) Characteristics of crop straw resources in China and its utilization. Resources Science, 25, 62-67 (in Chinese).

\section{Appendix A}

In this Appendix, the Database of SOC Experiments in Agricultural Soils in China is shown in detail. The experimental data of nitrogen fertilizer application, straw return and NT are laid out in three tables. Each table contains the following information:

1. in which agricultural region the experiment was sited;

2. the name of the site;

3. the period of the experiment;

4. the crop planted in the experiment site;

5. treatments;

6. soil carbon change with and without carbon sequestration measure;

7. carbon sequestration rate;

8. references.

Because a large area of China's cropland crops two times a year, farmers may adopt NT for one crop but plow the cropland for the second crop in the same year. We also put the data of 'reduced tillage' treatment into our database of NT.

For a few pairs of data, soil carbon change data are not available because their original reports of the experiment did not give the soil carbon change of each treatment, but directly reported the difference of soil carbon change between the treatments or the value of carbon sequestration rate.

A full list of the references is also given at the end of this Appendix. 
296 F. LU et al.

Table A1 Experimental data of nitrogen fertilizer application

\begin{tabular}{|c|c|c|c|c|c|c|c|c|}
\hline \multirow{2}{*}{$\begin{array}{l}\text { Agricultural } \\
\text { region }\end{array}$} & \multirow{2}{*}{ Site } & \multirow{2}{*}{$\begin{array}{l}\text { Period } \\
\text { (years) }\end{array}$} & \multirow[b]{2}{*}{ Crop } & \multirow{2}{*}{$\begin{array}{l}\text { Fertilizer } \\
\left(\mathrm{kg} \mathrm{Nha}^{-1} \mathrm{yr}^{-1}\right)\end{array}$} & \multicolumn{2}{|c|}{$\begin{array}{l}\text { Carbon change } \\
\left(\mathrm{g} \mathrm{m}^{-2} \mathrm{yr}^{-1}\right)\end{array}$} & \multirow{2}{*}{$\begin{array}{l}\text { Carbon } \\
\text { sequestration } \\
\text { rate } \\
\left(\mathrm{kgCha}^{-1} \mathrm{yr}^{-1}\right)\end{array}$} & \multirow[b]{2}{*}{ Reference } \\
\hline & & & & & Control & Treatment & & \\
\hline \multirow[t]{5}{*}{ I } & $\begin{array}{l}\text { Liaoning } \\
\text { Academy of } \\
\text { Agricultural } \\
\text { Sciences }\end{array}$ & 10 & Maize & 75 & -5.80 & -6.96 & -11.60 & Wu (1996) \\
\hline & & 10 & & 75 & -2.32 & 0 & 23.20 & \\
\hline & & & & 75 & 2.320 & 3.480 & 11.6 & \\
\hline & & & & 75 & -3.480 & 8.121 & 116 & \\
\hline & & & & 75 & 25.52 & 19.72 & -58 & \\
\hline \multirow[t]{2}{*}{ I } & Tonghua, Jilin & 5 & Paddy rice & 150 & 11.60 & 26.10 & 145.0 & Liu et al. (1992) \\
\hline & & 5 & & 150 & 14.50 & 29.00 & 145.0 & \\
\hline \multirow[t]{3}{*}{ I } & $\begin{array}{l}\text { Shenyang, } \\
\text { Liaoning }\end{array}$ & 14 & Maize & 90 & -11.60 & -12.49 & -8.924 & Han et al. (1995) \\
\hline & & & & 90 & 23.20 & 20.52 & -26.77 & \\
\hline & & & & 90 & 30.34 & 31.23 & 8.924 & \\
\hline \multirow[t]{2}{*}{ I } & $\begin{array}{l}\text { Hailun, } \\
\text { Heilongjiang }\end{array}$ & 16 & $\begin{array}{l}\text { Rotation of } \\
\text { maize } \\
\text { and } \\
\text { wheat }\end{array}$ & 107.2 & 80.18 & 65.80 & -143.8 & Shi et al. (2002) \\
\hline & & & & 107.2 & & & 112.3 & \\
\hline I & $\begin{array}{l}\text { Shenyang, } \\
\text { Liaoning }\end{array}$ & 8 & Maize & 135 & -19.24 & 16.52 & 357.5 & Mu et al. (1998) \\
\hline \multirow[t]{2}{*}{ I } & & 9 & & 21 & 2.578 & 7.734 & 51.56 & Liu et al. (1998) \\
\hline & & 9 & & 21 & 20.62 & 15.47 & -51.56 & \\
\hline \multirow[t]{2}{*}{ I } & $\begin{array}{l}\text { Dongning, } \\
\text { Heilongjiang }\end{array}$ & 9 & Paddy rice & 138 & 112.2 & 146.0 & 338.0 & Jin et al. (1993) \\
\hline & & 9 & & 138 & 0 & -4.609 & -46.09 & \\
\hline \multirow[t]{2}{*}{ I } & Tonghua, Jilin & 5 & Paddy rice & 120 & 11.25 & 25.32 & 140.7 & Liu et al. (1991) \\
\hline & & 5 & & 120 & 14.07 & 28.13 & 140.7 & \\
\hline II & $\begin{array}{l}\text { Changping, } \\
\text { Beijing }\end{array}$ & 4 & $\begin{array}{l}\text { Maize- } \\
\text { wheat }\end{array}$ & 300 & 13.88 & 37.00 & 231.3 & $\begin{array}{l}\text { Chen et al. } \\
\text { (1996) }\end{array}$ \\
\hline II & $\begin{array}{l}\text { Zhengzhou, } \\
\text { Henan }\end{array}$ & 15 & $\begin{array}{l}\text { Maize-- } \\
\text { wheat }\end{array}$ & 240 & -14.85 & 5.568 & 204.2 & $\begin{array}{l}\text { Sun \& Wang } \\
\quad(2002)\end{array}$ \\
\hline \multirow[t]{2}{*}{ II } & $\begin{array}{l}\text { Laiyang, } \\
\text { Shandong }\end{array}$ & 25 & $\begin{array}{l}\text { Maize- } \\
\text { wheat }\end{array}$ & 138 & 24.83 & 39.01 & 141.8 & Liu et al. (2005) \\
\hline & & 25 & & 276 & 24.83 & 38.67 & 138.4 & \\
\hline \multirow[t]{4}{*}{ II } & Runan, Henan & 16 & $\begin{array}{l}\text { Maize- } \\
\text { wheat }\end{array}$ & 67.5 & -3.799 & 4.749 & 85.48 & Sun et al. (1999) \\
\hline & & 16 & & 135 & -3.799 & 8.548 & 123.5 & \\
\hline & & & & 67.5 & 1.900 & 9.498 & 75.99 & \\
\hline & & & & 135 & 1.900 & 2.849 & 9.498 & \\
\hline II & & & & 300 & -5 & 7.954 & 129.5 & $\begin{array}{l}\text { Meng et al. } \\
\quad(2005)\end{array}$ \\
\hline \multirow[t]{6}{*}{ II } & $\begin{array}{l}\text { Changping, } \\
\text { Beijing }\end{array}$ & 20 & $\begin{array}{l}\text { Maize- } \\
\text { wheat }\end{array}$ & 135 & -11.92 & -4.061 & 78.60 & $\begin{array}{l}\text { Huang \& Sun } \\
\quad(2006)\end{array}$ \\
\hline & & 20 & & 270 & -11.92 & 1.179 & 131.0 & \\
\hline & & 20 & & 135 & -5.109 & 1.965 & 70.74 & \\
\hline & & 20 & & 270 & -5.109 & 9.825 & 149.3 & \\
\hline & & 20 & & 135 & 2.096 & 4.192 & 20.96 & \\
\hline & & 20 & & 270 & 2.096 & 19.26 & 171.6 & \\
\hline \multirow[t]{2}{*}{ II } & $\begin{array}{l}\text { Changping, } \\
\text { Beijing }\end{array}$ & 13 & & 150 & 24.82 & 31.30 & 64.86 & Song et al. (2007) \\
\hline & & 13 & & 150 & 40.18 & 33.98 & -62.04 & \\
\hline
\end{tabular}

Continued 
Table A1. (Contd.)

\begin{tabular}{|c|c|c|c|c|c|c|c|c|}
\hline \multirow{2}{*}{$\begin{array}{l}\text { Agricultural } \\
\text { region }\end{array}$} & \multirow{2}{*}{ Site } & \multirow{2}{*}{$\begin{array}{l}\text { Period } \\
\text { (years) }\end{array}$} & \multirow[b]{2}{*}{ Crop } & \multirow{2}{*}{$\begin{array}{l}\text { Fertilizer } \\
\left(\mathrm{kg} \mathrm{Nha}^{-1} \mathrm{yr}^{-1}\right)\end{array}$} & \multicolumn{2}{|c|}{$\begin{array}{l}\text { Carbon change } \\
\left(\mathrm{g} \mathrm{m}^{-2} \mathrm{yr}^{-1}\right)\end{array}$} & \multirow{2}{*}{$\begin{array}{l}\text { Carbon } \\
\text { sequestration } \\
\text { rate } \\
\left(\mathrm{kgCha}^{-1} \mathrm{yr}^{-1}\right)\end{array}$} & \multirow{2}{*}{ Reference } \\
\hline & & & & & Control & Treatment & & \\
\hline \multirow[t]{2}{*}{ II } & $\begin{array}{l}\text { Changping, } \\
\text { Beijing }\end{array}$ & 13 & & 150 & -29.23 & -30.65 & -14.26 & Liu et al. (2007) \\
\hline & & 13 & & 150 & -23.24 & -6.979 & 162.6 & \\
\hline II & Henan & 10 & & 300 & 12.49 & 20.81 & 83.25 & Xu et al. (2006a) \\
\hline II & $\begin{array}{l}\text { Changping, } \\
\text { Beijing }\end{array}$ & 10 & & 300 & -42.52 & -23.46 & 190.6 & Xu et al. (2006a) \\
\hline III & $\begin{array}{l}\text { Fukang, } \\
\quad \text { Xinjiang }\end{array}$ & 9 & Wheat & 150 & 10.83 & 25.26 & 144.4 & $\begin{array}{l}\text { Zhou \& Wang } \\
\text { (2003) }\end{array}$ \\
\hline \multirow[t]{2}{*}{ III } & $\begin{array}{l}\text { Yangling, } \\
\text { Shaanxi }\end{array}$ & 7 & & 315 & -19.69 & 25.85 & 455.4 & $\begin{array}{l}\text { Zhou et al. } \\
\text { (1993) }\end{array}$ \\
\hline & & & & 315 & -33.41 & 7.955 & 413.66 & \\
\hline III & & & & 90 & & & -180 & Wu et al. (2004) \\
\hline III & $\begin{array}{l}\text { Pingliang, } \\
\text { Gansu }\end{array}$ & 24 & $\begin{array}{l}\text { Rotation of } \\
\text { maize } \\
\text { and } \\
\text { wheat }\end{array}$ & 90 & -5.06 & 3.63 & 86.93 & Fan et al. (2005) \\
\hline \multirow[t]{10}{*}{ III } & $\begin{array}{l}\text { Changwu, } \\
\text { Shaanxi }\end{array}$ & 15 & Wheat & 120 & 1.569 & 3.608 & 20.39 & Fan et al. (2003) \\
\hline & & 15 & & 120 & 3.696 & 15.27 & 116.6 & \\
\hline & & 16 & & 90 & 1.279 & 2.241 & 9.625 & \\
\hline & & 16 & & 180 & 1.279 & 4.318 & 30.39 & \\
\hline & & 16 & & 45 & 0.0825 & 4.070 & 39.88 & \\
\hline & & 16 & & 90 & 0.0825 & 7.109 & 70.26 & \\
\hline & & 16 & & 135 & 0.0825 & 10.22 & 101.3 & \\
\hline & & 16 & & 180 & 0.0825 & 9.020 & 89.38 & \\
\hline & & 16 & & 90 & -0.9487 & 10.62 & 115.6 & \\
\hline & & 16 & & 180 & -0.9487 & 10.05 & 110 & \\
\hline III & Zhangye, Gansu & 10 & Wheat & 156 & -45.24 & -52.78 & -75.41 & Jin \& Ma (1995) \\
\hline \multirow[t]{2}{*}{ III } & $\begin{array}{l}\text { Changwu, } \\
\text { Shaanxi }\end{array}$ & 8 & Wheat & 120 & 0.000 & 17.55 & 175.5 & $\begin{array}{l}\text { Dang et al. } \\
\text { (1993) }\end{array}$ \\
\hline & & & & 120 & -7.976 & 9.571 & 175.5 & \\
\hline \multirow[t]{2}{*}{ III } & Zhangye, Gansu & 11 & Wheat & 299 & -56.23 & -37.92 & 183.1 & Yang et al. (2005) \\
\hline & & & & 299 & -41.85 & -32.69 & 91.54 & \\
\hline \multirow[t]{2}{*}{ III } & Zhangye, Gansu & 11 & Wheat & 225.4 & -39.49 & -19.62 & 198.8 & $\begin{array}{l}\text { Chen \& Zou } \\
\text { (2005) }\end{array}$ \\
\hline & & & & 225.4 & -23.54 & -18.31 & 52.31 & \\
\hline \multirow[t]{2}{*}{ III } & $\begin{array}{r}\text { Zhenyuan, } \\
\text { Shaanxi }\end{array}$ & 4 & Wheat & 120 & -6.902 & 13.80 & 207.1 & Liu (2003) \\
\hline & & & & 120 & 10.35 & 20.71 & 103.5 & \\
\hline III & $\begin{array}{l}\text { Tangling, } \\
\text { Shaanxi }\end{array}$ & 7 & Wheat & 240 & -3.977 & 12.13 & 161.1 & $\begin{array}{l}\text { Wang et al. } \\
\text { (2000a) }\end{array}$ \\
\hline III & $\begin{array}{l}\text { Pingliang, } \\
\text { Gansu }\end{array}$ & 9 & $\begin{array}{l}\text { Maize- } \\
\text { wheat }\end{array}$ & 180 & -1.680 & 16.80 & 184.8 & $\begin{array}{l}\text { Jiang \& Zhou } \\
\text { (1994) }\end{array}$ \\
\hline III & Shaanxi & 10 & & 300 & -35.35 & -41.86 & -65.08 & Xu et al. (2006a) \\
\hline III & Xinjiang & 10 & & 300 & 1.885 & 8.121 & 62.35 & \\
\hline IV & $\begin{array}{l}\text { Southwest } \\
\text { University, } \\
\text { Chongqing }\end{array}$ & 9 & Paddy rice & 240 & -21.28 & -14.73 & 65.48 & $\begin{array}{l}\text { Yuan et al. } \\
\text { (1993) }\end{array}$ \\
\hline IV & Fuzhou, Fujian & 10 & Paddy rice & 240 & 51.57 & 63.35 & 117.9 & Liu et al. (1994) \\
\hline IV & $\begin{array}{l}\text { Southwest } \\
\text { University, } \\
\text { Chongqing }\end{array}$ & 8 & Paddy Rice & 150 & 78.03 & 78.20 & 1.711 & $\begin{array}{l}\text { Wang et al. } \\
\qquad(2005)\end{array}$ \\
\hline
\end{tabular}


298 F. LU et al.

\begin{tabular}{|c|c|c|c|c|c|c|c|c|}
\hline \multirow[b]{2}{*}{$\begin{array}{l}\text { Agricultural } \\
\text { region }\end{array}$} & \multirow[b]{2}{*}{ Site } & \multirow[b]{2}{*}{$\begin{array}{l}\text { Period } \\
\text { (years) }\end{array}$} & \multirow[b]{2}{*}{ Crop } & \multirow[b]{2}{*}{$\begin{array}{l}\text { Fertilizer } \\
\left(\mathrm{kgNha}^{-1} \mathrm{yr}^{-1}\right)\end{array}$} & \multicolumn{2}{|c|}{$\begin{array}{l}\text { Carbon change } \\
\left(\mathrm{g} \mathrm{m}^{-2} \mathrm{yr}^{-1}\right)\end{array}$} & \multirow{2}{*}{$\begin{array}{l}\text { Carbon } \\
\text { sequestration } \\
\text { rate } \\
\left(\mathrm{kgCha}^{-1} \mathrm{yr}^{-1}\right)\end{array}$} & \multirow{2}{*}{ Reference } \\
\hline & & & & & Control & Treatment & & \\
\hline IV & Juning, Jiangsu & 6 & $\begin{array}{l}\text { Wheat- } \\
\text { maize }\end{array}$ & 384.6 & -54.29 & 19.52 & 738.1 & Sun et al. (1996) \\
\hline IV & Xuzhou, Jiangsu & 19 & Paddy rice & 300 & -12.22 & 2.064 & 142.9 & $\begin{array}{l}\text { Zhang \& Zhang } \\
\text { (2002) }\end{array}$ \\
\hline \multirow[t]{2}{*}{ IV } & $\begin{array}{l}\text { Wengyuan, } \\
\text { Guangdong }\end{array}$ & 6 & Paddy rice & 300 & -39.12 & -32.64 & 64.77 & Tan et al. (1990) \\
\hline & $\begin{array}{l}\text { Taishan, } \\
\text { Guangdong }\end{array}$ & 4 & Paddy rice & 299.4 & -64.12 & -64.51 & -3.886 & \\
\hline IV & $\begin{array}{l}\text { Taoyuan, } \\
\text { Hunan }\end{array}$ & 9 & Paddy rice & 244.7 & -21.78 & -8.378 & 134.0 & $\begin{array}{l}\text { Zhou et al. } \\
\text { (2002) }\end{array}$ \\
\hline IV & $\begin{array}{l}\text { Taoyuan, } \\
\text { Hunan }\end{array}$ & 12 & Paddy rice & 229.1 & -3.770 & 6.284 & 100.5 & $\begin{array}{l}\text { Wang et al. } \\
\text { (2004) }\end{array}$ \\
\hline \multirow[t]{2}{*}{ IV } & Yingtan, Jiangxi & 20 & Paddy rice & 230 & & & 109.2 & $\begin{array}{c}\text { Zhang et al. } \\
\text { (2006) }\end{array}$ \\
\hline & & 20 & Paddy rice & 230 & & & 70.2 & \\
\hline IV & $\begin{array}{l}\text { Mengchang, } \\
\text { Anhui }\end{array}$ & 10 & Wheat & 187.5 & 18.10 & 42.23 & 241.3 & $\begin{array}{l}\text { Wang et al. } \\
\quad(2007)\end{array}$ \\
\hline \multirow[t]{2}{*}{ IV } & Qiyang, Hunan & 10 & $\begin{array}{l}\text { Maize- } \\
\text { wheat }\end{array}$ & 300 & 96.22 & 102.1 & 58.82 & Xu et al. (2006b) \\
\hline & & 10 & $\begin{array}{l}\text { Maize- } \\
\text { wheat }\end{array}$ & 300 & 43.74 & 41.32 & -24.13 & \\
\hline IV & Jinxian, Jiangxi & 9 & & 190 & 148.7 & 152.0 & 32.56 & Lai et al. (1992) \\
\hline IV & & 9 & & 190 & 152.3 & 156.6 & 42.55 & \\
\hline
\end{tabular}

Table A2 Experimental data of straw return

\begin{tabular}{|c|c|c|c|c|c|c|c|c|}
\hline \multirow{2}{*}{$\begin{array}{l}\text { Agricultural } \\
\text { region }\end{array}$} & \multirow{2}{*}{ Site } & \multirow{2}{*}{$\begin{array}{l}\text { Period } \\
\text { (years) }\end{array}$} & \multirow[b]{2}{*}{ Crop } & \multirow{2}{*}{$\begin{array}{l}\text { Amount of } \\
\text { air-dried straw } \\
\text { returned } \\
\left(\mathrm{tha}^{-1} \mathrm{yr}^{-1}\right)\end{array}$} & \multicolumn{2}{|c|}{$\begin{array}{l}\text { Carbon change } \\
\left(\mathrm{g} \mathrm{m}^{-2} \mathrm{yr}^{-1}\right)\end{array}$} & \multirow{2}{*}{$\begin{array}{l}\text { Carbon } \\
\text { sequestration } \\
\text { rate } \\
\left(\mathrm{kgCha}^{-1} \mathrm{yr}^{-1}\right)\end{array}$} & \multirow[b]{2}{*}{ Reference } \\
\hline & & & & & Control & Treatment & & \\
\hline I & $\begin{array}{l}\text { Ha'erbin, } \\
\text { Heilongjiang }\end{array}$ & 5 & $\begin{array}{l}\text { Rotation of } \\
\text { wheat } \\
\text { and } \\
\text { maize }\end{array}$ & 4.688 & -20.34 & 96.62 & 1170 & $\begin{array}{c}\text { Zeng et al. } \\
\text { (1985) }\end{array}$ \\
\hline \multirow[t]{4}{*}{ I } & $\begin{array}{l}\text { Heihe, } \\
\text { Heilongjiang }\end{array}$ & 12 & Wheat & 2 & -59.77 & -15.50 & 442.8 & Zhang 1998) \\
\hline & & 12 & & 2 & -26.57 & 21.03 & 476.0 & \\
\hline & & 12 & & 2 & -15.50 & 22.14 & 376.4 & \\
\hline & & 12 & & 2 & -8.855 & 6.642 & 155.0 & \\
\hline \multirow[t]{5}{*}{ I } & $\begin{array}{c}\text { Weitun Village, } \\
\text { Wafangdian, } \\
\text { Liaoning }\end{array}$ & 10 & Maize & 1.38 & -3.063 & 32.16 & 352.2 & $\begin{array}{l}\text { Zhao et al. } \\
\text { (1998) }\end{array}$ \\
\hline & & 10 & & 2.25 & -3.063 & 49.00 & 520.6 & \\
\hline & & 10 & & 3.75 & -3.063 & 75.03 & 781.0 & \\
\hline & $\begin{array}{l}\text { Zhangtun } \\
\text { Village, } \\
\text { Wafangdian, } \\
\text { Liaoning }\end{array}$ & 7 & Maize & 1.38 & -12.33 & 16.44 & 287.7 & \\
\hline & & 7 & & 2.25 & -12.33 & 34.94 & 472.6 & \\
\hline I & Fuxin, Liaoning & 3 & Maize & 7.5 & -144.1 & -21.34 & 1227 & Hou et al. (2004) \\
\hline
\end{tabular}




\begin{tabular}{|c|c|c|c|c|c|c|c|c|}
\hline \multirow{2}{*}{$\begin{array}{l}\text { Agricultural } \\
\text { region }\end{array}$} & \multirow{2}{*}{ Site } & \multirow{2}{*}{$\begin{array}{l}\text { Period } \\
\text { (years) }\end{array}$} & \multirow[b]{2}{*}{ Crop } & \multirow{2}{*}{$\begin{array}{l}\text { Amount of } \\
\text { air-dried straw } \\
\text { returned } \\
\left(\mathrm{tha}^{-1} \mathrm{yr}^{-1}\right)\end{array}$} & \multicolumn{2}{|c|}{$\begin{array}{l}\text { Carbon change } \\
\left(\mathrm{g} \mathrm{m}^{-2} \mathrm{yr}^{-1}\right)\end{array}$} & \multirow{2}{*}{$\begin{array}{l}\text { Carbon } \\
\text { sequestration } \\
\text { rate } \\
\left(\mathrm{kgC} \mathrm{ha}^{-1} \mathrm{yr}^{-1}\right)\end{array}$} & \multirow[b]{2}{*}{ Reference } \\
\hline & & & & & Control & Treatment & & \\
\hline I & $\begin{array}{l}\text { Shenyang, } \\
\text { Liaoning }\end{array}$ & 12 & Maize & 2.625 & -5.646 & 27.44 & 330.8 & Yan et al. (2004) \\
\hline I & Dehui, Jilin & 9 & Maize & 7.5 & 7.903 & 56.90 & 490.0 & Sun et al. (1992) \\
\hline \multirow[t]{2}{*}{ I } & $\begin{array}{l}\text { Heihe, } \\
\text { Heilongjiang }\end{array}$ & 9 & & 2 & -76.75 & -29.52 & 472.3 & Zhang (1989) \\
\hline & & 9 & & 2 & -28.04 & 32.47 & 605.1 & \\
\hline \multirow[t]{4}{*}{ I } & $\begin{array}{l}\text { Dongning, } \\
\text { Heilongjiang }\end{array}$ & 8 & Paddy rice & 11.663 & 0 & 76.82 & 768.2 & Jin et al. (1993) \\
\hline & & 8 & & 23.325 & 0 & 112.2 & 1122 & \\
\hline & & 8 & & 11.663 & -4.609 & 46.09 & 507.0 & \\
\hline & & 8 & & 23.325 & -4.609 & 146.0 & 1506 & \\
\hline \multirow[t]{2}{*}{ I } & Meihekou, Jilin & 5 & Paddy rice & 4.5 & 109.9 & 169.1 & 592.0 & Liu et al. (1990) \\
\hline & & 5 & & 4.5 & 98.66 & 160.7 & 620.2 & \\
\hline \multirow[t]{2}{*}{ I } & Tonghua, Jilin & 5 & Paddy rice & 4.5 & 11.25 & 64.70 & 534.5 & Liu et al. (1991) \\
\hline & & 5 & & 4.5 & 28.13 & 70.33 & 422.0 & \\
\hline \multirow[t]{3}{*}{ I } & $\begin{array}{l}\text { Gongzhuling, } \\
\text { Jilin }\end{array}$ & 5 & Maize & 3.847 & & & 314.6 & $\begin{array}{l}\text { Zheng et al. } \\
\text { (2006) }\end{array}$ \\
\hline & & 5 & & 3.847 & & & 284.0 & \\
\hline & & 5 & & 3.847 & & & 306.3 & \\
\hline I & Jilin & 10 & Maize & 5.771 & -280.37 & -264.78 & 155.9 & Xu et al. (2006a) \\
\hline \multirow[t]{2}{*}{ II } & $\begin{array}{l}\text { Shouyang, } \\
\text { Shaanxi }\end{array}$ & 5 & Maize & 6 & -41.74 & 53.66 & 954.1 & Yang et al. (1999) \\
\hline & & 5 & & 6 & -26.83 & 5.963 & 328.0 & \\
\hline \multirow[t]{4}{*}{ II } & $\begin{array}{l}\text { Luancheng } \\
\text { Experiment } \\
\text { Site, Hebei }\end{array}$ & 3 & $\begin{array}{l}\text { Maize- } \\
\text { wheat }\end{array}$ & 3.75 & -33.02 & -8.662 & 243.6 & $\begin{array}{l}\text { Zeng et al. } \\
\text { (1996) }\end{array}$ \\
\hline & & 3 & & 7.5 & -33.02 & 13.53 & 465.6 & \\
\hline & & 3 & & 7.5 & -33.02 & 29.78 & 628.0 & \\
\hline & & 3 & & 7.5 & -33.02 & 48.18 & 812.1 & \\
\hline \multirow[t]{4}{*}{ II } & Zunhua, Hebei & 8 & $\begin{array}{l}\text { Maize- } \\
\text { wheat }\end{array}$ & 4.5 & -17.27 & 56.48 & 737.5 & $\begin{array}{c}\text { Zhang et al. } \\
\text { (1999) }\end{array}$ \\
\hline & & 8 & & 4.2 & -17.27 & 51.88 & 691.5 & \\
\hline & Changli, Hebei & 8 & $\begin{array}{l}\text { Maize- } \\
\text { wheat }\end{array}$ & 4.5 & -9.379 & 29.27 & 386.5 & \\
\hline & & 8 & & 4.2 & -9.379 & 24.15 & 335.3 & \\
\hline \multirow[t]{2}{*}{ II } & Quzhou, Hebei & 11 & Wheat & 4.5 & 34.28 & 67.18 & 329.0 & Niu et al. (1998) \\
\hline & & 11 & & 2.25 & 42.50 & 50.73 & 82.26 & \\
\hline \multirow[t]{8}{*}{ II } & $\begin{array}{c}\text { Hengshui, } \\
\text { Hebei }\end{array}$ & 3 & $\begin{array}{l}\text { Maize- } \\
\text { wheat }\end{array}$ & 4.769 & -14.73 & 27.73 & 424.7 & $\begin{array}{l}\text { Zhang et al. } \\
\text { (1989) }\end{array}$ \\
\hline & & 3 & & 9.539 & -14.73 & 54.60 & 693.3 & \\
\hline & & 3 & & 4.769 & 6.933 & 32.93 & 260.0 & \\
\hline & & 3 & & 9.539 & 6.933 & 37.27 & 303.3 & \\
\hline & & 3 & & 4.769 & 33.80 & 103.1 & 693.3 & \\
\hline & & 3 & & 9.539 & 33.80 & 52.00 & 182.0 & \\
\hline & & 3 & & 4.769 & 0 & 20.80 & 208.0 & \\
\hline & & 3 & & 9.539 & 0 & 93.60 & 936.0 & \\
\hline II & Ling, Shandong & 4 & Wheat & 15 & 26.60 & 102.6 & 759.9 & $\begin{array}{l}\text { Zhang et al. } \\
\text { (1997) }\end{array}$ \\
\hline II & $\begin{array}{l}\text { Changping, } \\
\text { Beijing }\end{array}$ & 12 & $\begin{array}{l}\text { Maize- } \\
\text { wheat }\end{array}$ & 3 & 21.11 & 32.68 & 115.6 & Sun et al. (2003) \\
\hline II & $\begin{array}{c}\text { Changping, } \\
\text { Beijing }\end{array}$ & 8 & $\begin{array}{l}\text { Maize- } \\
\text { wheat }\end{array}$ & 2.233 & 41.10 & 80.50 & 394.0 & Song et al. (2002) \\
\hline
\end{tabular}


300 F. LU et al.

\begin{tabular}{|c|c|c|c|c|c|c|c|c|}
\hline \multirow{2}{*}{$\begin{array}{l}\text { Agricultural } \\
\text { region }\end{array}$} & \multirow[b]{2}{*}{ Site } & \multirow{2}{*}{$\begin{array}{l}\text { Period } \\
\text { (years) }\end{array}$} & \multirow[b]{2}{*}{ Crop } & \multirow{2}{*}{$\begin{array}{l}\text { Amount of } \\
\text { air-dried straw } \\
\text { returned } \\
\left(\mathrm{tha}^{-1} \mathrm{yr}^{-1}\right)\end{array}$} & \multicolumn{2}{|c|}{$\begin{array}{l}\text { Carbon change } \\
\left(\mathrm{g} \mathrm{m}^{-2} \mathrm{yr}^{-1}\right)\end{array}$} & \multirow{2}{*}{$\begin{array}{l}\text { Carbon } \\
\text { sequestration } \\
\text { rate } \\
\left(\mathrm{kgCha}^{-1} \mathrm{yr}^{-1}\right)\end{array}$} & \multirow{2}{*}{ Reference } \\
\hline & & & & & Control & Treatment & & \\
\hline & & 8 & & 3.333 & 41.10 & 125.6 & 844.5 & \\
\hline & & 8 & & 3.333 & 41.10 & 28.84 & -122.5 & \\
\hline \multirow[t]{2}{*}{ II } & \multirow[t]{2}{*}{$\begin{array}{c}\text { Hengshui, } \\
\text { Hebei }\end{array}$} & 7 & \multirow[t]{2}{*}{ Maize } & 3 & - & \multirow[t]{2}{*}{-} & 88.33 & \multirow[t]{2}{*}{$\begin{array}{l}\text { Zhang et al. } \\
\quad(2000)\end{array}$} \\
\hline & & 7 & & 7.5 & - & & 254.2 & \\
\hline II & $\begin{array}{l}\text { Hengshui, } \\
\text { Hebei }\end{array}$ & 24 & $\begin{array}{l}\text { Maize- } \\
\text { wheat }\end{array}$ & 1.5 & 2.074 & 7.855 & 57.81 & Li et al. (2007) \\
\hline II & $\begin{array}{l}\text { Changping, } \\
\text { Beijing }\end{array}$ & 13 & $\begin{array}{l}\text { Maize- } \\
\text { wheat }\end{array}$ & 3 & 32.99 & 70.78 & 377.9 & Song et al. (2007) \\
\hline II & \multirow[t]{3}{*}{$\begin{array}{l}\text { Hengshui, } \\
\text { Hebei }\end{array}$} & 12 & $\begin{array}{l}\text { Maize- } \\
\text { wheat }\end{array}$ & 2.25 & 15.63 & 35.50 & 198.7 & \multirow[t]{3}{*}{ Ma et al. (2007) } \\
\hline II & & 12 & $\begin{array}{l}\text { Maize- } \\
\text { wheat }\end{array}$ & 4.5 & 15.63 & 28.05 & 124.2 & \\
\hline II & & 12 & $\begin{array}{l}\text { Maize- } \\
\text { wheat }\end{array}$ & 9 & 15.63 & 40.46 & 248.3 & \\
\hline II & Henan & 10 & $\begin{array}{l}\text { Maize- } \\
\text { wheat }\end{array}$ & 8.476 & 24.81 & 75.88 & 510.7 & Xu et al. (2006a) \\
\hline III & $\begin{array}{c}\text { Pingliang, } \\
\text { Gansu }\end{array}$ & 9 & $\begin{array}{l}\text { Maize- } \\
\text { wheat }\end{array}$ & 7.5 & 16.80 & 31.91 & 151.2 & $\begin{array}{l}\text { Jiang \& Zhou } \\
\text { (1994) }\end{array}$ \\
\hline \multirow[t]{3}{*}{ III } & \multirow[t]{3}{*}{$\begin{array}{l}\text { Yangling, } \\
\text { Shaanxi }\end{array}$} & 21 & Maize & 3.474 & 2.297 & 12.67 & 103.7 & \multirow[t]{3}{*}{$\begin{array}{l}\text { Wang et al. } \\
\quad(2000 \mathrm{~b})\end{array}$} \\
\hline & & 21 & & 6.948 & 2.297 & 25.13 & 228.3 & \\
\hline & & 21 & & 13.897 & 2.297 & 27.49 & 252.0 & \\
\hline \multirow[t]{2}{*}{ III } & \multirow[t]{2}{*}{$\begin{array}{l}\text { Fukang, } \\
\quad \text { Xinjiang }\end{array}$} & 9 & Wheat & 2.25 & 25.26 & 28.87 & 36.09 & \multirow[t]{2}{*}{$\begin{array}{l}\text { Zhou \& Wang } \\
\quad(2003)\end{array}$} \\
\hline & & 9 & & 4.5 & 25.26 & 34.29 & 90.23 & \\
\hline III & $\begin{array}{r}\text { Jinchuan, } \\
\text { Gansu }\end{array}$ & 20 & Wheat & 3.75 & - & - & 135.0 & Wu et al. (2004) \\
\hline III & $\begin{array}{l}\text { Pingliang, } \\
\text { Gansu }\end{array}$ & 19 & Wheat & 3.75 & 12.08 & 39.57 & 274.9 & Fan et al. (2005) \\
\hline \multirow[t]{3}{*}{ III } & \multirow[t]{3}{*}{$\begin{array}{l}\text { Yangling } \\
\text { Shaanxi }\end{array}$} & 20 & Maize & 3.474 & 1.659 & 16.51 & 148.5 & \multirow[t]{3}{*}{$\begin{array}{l}\text { Guan et al. } \\
\quad(2002)\end{array}$} \\
\hline & & 20 & & 6.948 & 1.659 & 21.04 & 193.8 & \\
\hline & & 20 & & 13.897 & 1.659 & 32.35 & 306.9 & \\
\hline \multirow[t]{3}{*}{ III } & \multirow[t]{3}{*}{$\begin{array}{l}\text { Yangling, } \\
\text { Shaanxi }\end{array}$} & 25 & Maize & 3.474 & 84.15 & 86.77 & 26.21 & \multirow[t]{3}{*}{ Sun et al. (2005) } \\
\hline & & 25 & & 6.948 & 84.15 & 116.9 & 327.6 & \\
\hline & & 25 & & 13.897 & 84.15 & 105.4 & 212.5 & \\
\hline III & $\begin{array}{l}\text { Yangling, } \\
\text { Shaanxi }\end{array}$ & 23 & Maize & 3.474 & 7.414 & 6.204 & -12.10 & Xie et al. (2004) \\
\hline & & 23 & & 6.948 & 7.414 & 22.09 & 146.8 & \\
\hline & & 23 & & 13.897 & 7.414 & 27.69 & 202.8 & \\
\hline III & $\begin{array}{c}\text { Toudaoyuan, } \\
\text { Yangling, } \\
\text { Shaanxi }\end{array}$ & 12 & Maize & 4.5 & 36.57 & 43.11 & 65.35 & Gu et al. (2004) \\
\hline III & $\begin{array}{l}\text { Yangling, } \\
\text { Shaanxi }\end{array}$ & 24 & Maize & 3.474 & 11.60 & 19.72 & 81.21 & Li (2007) \\
\hline & & 24 & & 6.948 & 11.60 & 27.26 & 156.6 & \\
\hline & & 24 & & 13.897 & 11.60 & 35.38 & 237.8 & \\
\hline III & $\begin{array}{l}\text { Fukang, } \\
\quad \text { Xinjiang }\end{array}$ & 13 & & 2.25 & 28.73 & 32.09 & 33.55 & $\begin{array}{l}\text { Zhou et al. } \\
\quad(2007 \mathrm{a})\end{array}$ \\
\hline III & Shaanxi & 10 & & 5.662 & -22.08 & -0.1276 & 219.5 & Xu et al. (2006) \\
\hline
\end{tabular}




\begin{tabular}{|c|c|c|c|c|c|c|c|c|}
\hline \multirow{2}{*}{$\begin{array}{l}\text { Agricultural } \\
\text { region }\end{array}$} & \multirow[b]{2}{*}{ Site } & \multirow{2}{*}{$\begin{array}{l}\text { Period } \\
\text { (years) }\end{array}$} & \multirow[b]{2}{*}{ Crop } & \multirow{2}{*}{$\begin{array}{l}\text { Amount of } \\
\text { air-dried straw } \\
\text { returned } \\
\left(\mathrm{t} \mathrm{ha}^{-1} \mathrm{yr}^{-1}\right)\end{array}$} & \multicolumn{2}{|c|}{$\begin{array}{l}\text { Carbon change } \\
\left(\mathrm{g} \mathrm{m}^{-2} \mathrm{yr}^{-1}\right)\end{array}$} & \multirow{2}{*}{$\begin{array}{l}\text { Carbon } \\
\text { sequestration } \\
\text { rate } \\
\left(\mathrm{kgCha}^{-1} \mathrm{yr}^{-1}\right)\end{array}$} & \multirow[b]{2}{*}{ Reference } \\
\hline & & & & & Control & Treatment & & \\
\hline & Xinjiang & 10 & & 3.313 & 28.13 & 11.89 & -162.4 & \\
\hline \multirow[t]{2}{*}{ IV } & $\begin{array}{l}\text { Nantong, } \\
\text { Jiangsu }\end{array}$ & 3 & $\begin{array}{l}\text { Wheat- } \\
\text { paddy } \\
\text { rice }\end{array}$ & 3.75 & -23.61 & 46.56 & 701.7 & Li \& Xu (1987) \\
\hline & & 3 & & 3.75 & 11.14 & 51.38 & 402.4 & \\
\hline IV & $\begin{array}{l}\text { Nanchang City, } \\
\text { Jiangxi }\end{array}$ & 5 & Paddy Rice & 2.25 & 140.6 & 171.7 & 311.2 & Liu et al. (1984) \\
\hline \multirow[t]{2}{*}{ IV } & $\begin{array}{l}\text { Taizhou, } \\
\text { Jiangsu }\end{array}$ & 4 & Paddy rice & 1.5 & -15.20 & 11.40 & 266.0 & $\begin{array}{l}\text { Wang et al. } \\
\text { (2004) }\end{array}$ \\
\hline & & 4 & & 2.25 & -15.20 & 56.99 & 721.9 & \\
\hline \multirow[t]{2}{*}{ IV } & $\begin{array}{c}\text { Jiangyan, } \\
\text { Jiangsu }\end{array}$ & 3 & Paddy rice & 2.25 & -10.60 & 59.86 & 704.6 & Qian et al. (1998) \\
\hline & & 3 & & 2.25 & -10.59 & 50.66 & 612.5 & \\
\hline IV & Suzhou, Jiangsu & 4 & Paddy rice & 3.75 & -58.16 & 25.94 & 841.0 & $\begin{array}{l}\text { Wang et al. } \\
\text { (2003) }\end{array}$ \\
\hline \multirow[t]{3}{*}{ IV } & $\mathrm{Wu}$, Jiangsu & 5 & $\begin{array}{l}\text { Wheat- } \\
\text { paddy } \\
\text { rice }\end{array}$ & 2.25 & 14.14 & 62.02 & 478.8 & Sun et al. (1994) \\
\hline & & 5 & & 2.25 & 14.14 & 76.15 & 620.2 & \\
\hline & & 5 & & 4.5 & 14.14 & 136.8 & 1227 & \\
\hline \multirow[t]{2}{*}{ IV } & Fuzhou, Fujian & 3 & Paddy rice & 3.752 & 34.03 & 55.30 & 212.7 & Ren et al. (1993) \\
\hline & & 3 & & 3.752 & 153.1 & 178.6 & 255.2 & \\
\hline \multirow[t]{5}{*}{ IV } & $\begin{array}{l}\text { Southwest } \\
\text { University, } \\
\text { Chongqing }\end{array}$ & 8 & Paddy rice & 7.5 & -5.183 & 87.27 & 924.5 & $\begin{array}{l}\text { Wang et al. } \\
\text { (2005) }\end{array}$ \\
\hline & & 8 & & 7.5 & 11.30 & 90.36 & 790.6 & \\
\hline & & 8 & & 7.5 & 15.05 & 97.48 & 824.3 & \\
\hline & & 8 & & 7.5 & 28.91 & 105.0 & 760.6 & \\
\hline & & 8 & & 7.5 & 35.28 & 112.8 & 775.6 & \\
\hline IV & Longji, Zhejiang & 6 & Paddy rice & 15 & 271.2 & 390.8 & 1196 & Yin et al. (1995) \\
\hline IV & $\begin{array}{l}\text { Southwest } \\
\text { University, } \\
\text { Chongqing }\end{array}$ & 3 & Paddy rice & 7.5 & 4.563 & 82.13 & 775.7 & $\begin{array}{l}\text { Chen et al. } \\
\quad \text { (1995) }\end{array}$ \\
\hline \multirow[t]{3}{*}{ IV } & Jiangle, Fujian & 5 & Paddy rice & 4.5 & 23.08 & 40.03 & 169.5 & Chen (2000) \\
\hline & & 5 & & 4.5 & 59.45 & 89.49 & 300.3 & \\
\hline & & 5 & & 4.5 & 35.73 & 78.04 & 423.1 & \\
\hline IV & Suizhou, Hubei & 3 & Paddy rice & 3 & 283.8 & 335.2 & 513.3 & Qiu et al. (1998) \\
\hline IV & Zaoyang, Hubei & 3 & Paddy rice & 3 & 207.9 & 229.9 & 220.0 & \\
\hline IV & Dawu, Hubei & 3 & Paddy rice & 2.775 & 0.5955 & 88.60 & 880.0 & \\
\hline IV & $\begin{array}{l}\text { Yingcheng, } \\
\text { Hubei }\end{array}$ & 10 & Paddy rice & 2.775 & 0.2960 & 57.50 & 572.0 & \\
\hline IV & $\begin{array}{l}\text { Wangcheng, } \\
\text { Hunan }\end{array}$ & 10 & Paddy rice & 5.25 & 0.7554 & 13.96 & 132.0 & \\
\hline IV & Fuzhou, Fujian & 10 & Paddy rice & 9 & 375.3 & 412.1 & 367.5 & Lin et al. (1994) \\
\hline IV & $\begin{array}{l}\text { Shunchang, } \\
\text { Fujian }\end{array}$ & 10 & Paddy rice & 9 & 429.5 & 474.9 & 454.3 & \\
\hline IV & $\begin{array}{c}\text { Quzhou City, } \\
\text { Zhejiang }\end{array}$ & 7 & Paddy rice & 5.625 & 20.66 & 122.7 & 1020 & $\begin{array}{l}\text { Zhang \& Zhang } \\
\text { (1991) }\end{array}$ \\
\hline IV & Yandu, Jiangsu & 3 & Paddy rice & 2.625 & -4.950 & 39.60 & 445.5 & Dai et al. (2001) \\
\hline IV & $\begin{array}{l}\text { Jiaxing, } \\
\text { Zhejiang }\end{array}$ & 9 & Paddy rice & 2.175 & 15.71 & 47.13 & 314.2 & $\begin{array}{l}\text { Zhou \& Ni } \\
\quad \text { (1995) }\end{array}$ \\
\hline
\end{tabular}


Table A3 Experimental data of no-tillage

\begin{tabular}{|c|c|c|c|c|c|c|c|c|}
\hline \multirow[b]{2}{*}{$\begin{array}{l}\text { Agricultural } \\
\text { region }\end{array}$} & \multirow[b]{2}{*}{ Site } & \multirow[b]{2}{*}{$\begin{array}{l}\text { Period } \\
\text { (years) }\end{array}$} & \multirow[b]{2}{*}{ Crop } & \multirow[b]{2}{*}{$\begin{array}{l}\text { Tillage } \\
\text { treatment }\end{array}$} & \multicolumn{2}{|c|}{$\begin{array}{l}\text { Carbon change } \\
\left(\mathrm{g} \mathrm{m}^{-2} \mathrm{yr}^{-1}\right)\end{array}$} & \multirow{2}{*}{$\begin{array}{l}\text { Carbon } \\
\text { sequestration } \\
\text { rate } \\
\left(\mathrm{kgCha}^{-1} \mathrm{yr}^{-1}\right)\end{array}$} & \multirow{2}{*}{ Reference } \\
\hline & & & & & Control & Treatment & & \\
\hline I & $\begin{array}{l}\text { Mishan, } \\
\text { Helongjiang }\end{array}$ & 12 & $\begin{array}{l}\text { Rotation of } \\
\text { maize } \\
\text { and } \\
\text { wheat }\end{array}$ & No & 13.92 & 39.44 & 255.2 & Tian et al. (2002) \\
\hline II & $\begin{array}{l}\text { Yiding Basin, } \\
\text { Shaanxi }\end{array}$ & 3 & Maize & No & 6.570 & 18.93 & 123.6 & $\begin{array}{c}\text { Fan \& Chi } \\
\quad(1993)\end{array}$ \\
\hline II & $\begin{array}{l}\text { Pianguan, } \\
\text { Shaanxi }\end{array}$ & 6 & Maize & No & 5.259 & 28.92 & 236.6 & $\begin{array}{l}\text { Yuan et al. } \\
\text { (2004) }\end{array}$ \\
\hline II & $\begin{array}{l}\text { China } \\
\text { Agricultural } \\
\text { University, } \\
\text { Beijing }\end{array}$ & 9 & $\begin{array}{l}\text { Maize-- } \\
\text { wheat }\end{array}$ & No & 91.58 & 104.7 & 130.8 & $\begin{array}{c}\text { Gao \& Zhu } \\
\text { (1994) }\end{array}$ \\
\hline II & $\begin{array}{l}\text { Luancheng, } \\
\text { Hebei }\end{array}$ & 4 & $\begin{array}{l}\text { Maize- } \\
\text { wheat }\end{array}$ & No & & & 108.8 & $\begin{array}{l}\text { Zhou et al. } \\
\text { (2007b) }\end{array}$ \\
\hline II & $\begin{array}{l}\text { Wuchuan, Inner } \\
\text { Mongolia }\end{array}$ & 3 & Naked oats & No & & & 183.2 & Qin et al. (2007) \\
\hline III & $\begin{array}{l}\text { Linze County, } \\
\text { Gansu }\end{array}$ & 5 & Maize & No & 0 & 38.98 & 389.8 & Qin (2005) \\
\hline \multirow[t]{2}{*}{ IV } & $\begin{array}{l}\text { Yangzhou } \\
\text { University, } \\
\text { Jiangsu }\end{array}$ & 10 & $\begin{array}{c}\text { Paddy rice- } \\
\text { wheat }\end{array}$ & Reduced & 106.0 & 116.9 & 108.4 & $\begin{array}{c}\text { Huang et al. } \\
\text { (1999) }\end{array}$ \\
\hline & & 10 & & No & 106.0 & 129.6 & 235.5 & \\
\hline \multirow[t]{4}{*}{ IV } & $\begin{array}{l}\text { Yangzhou } \\
\text { University, } \\
\text { Jiangsu }\end{array}$ & 11 & $\begin{array}{c}\text { Paddy rice- } \\
\text { wheat }\end{array}$ & Reduced & 83.26 & 93.40 & 101.4 & $\begin{array}{c}\text { Liu \& Shen } \\
\text { (1996) }\end{array}$ \\
\hline & & 11 & & No- & 83.26 & 122.7 & 394.9 & \\
\hline & & 11 & & Reduced & 75.66 & 86.47 & 108.1 & \\
\hline & & 11 & & No & 75.66 & 97.47 & 218.1 & \\
\hline \multirow[t]{2}{*}{ IV } & $\begin{array}{c}\text { Zhangjiagang, } \\
\text { Jiangsu }\end{array}$ & 12 & $\begin{array}{l}\text { Paddy rice- } \\
\text { wheat }\end{array}$ & No & -9.34 & -6.67 & 26.68 & Gao et al. (2000) \\
\hline & & 12 & & No & 41.33 & 58.67 & 173.4 & \\
\hline IV & $\begin{array}{l}\text { Beipei, } \\
\text { Chongqing }\end{array}$ & 13 & Paddy rice & No & & & 112.3 & $\begin{array}{r}\text { Tang et al. } \\
\text { (2007a) }\end{array}$ \\
\hline IV & Shifang, Sichuan & 12 & $\begin{array}{l}\text { Paddy rice- } \\
\text { rapeseeds }\end{array}$ & No & & & 544.2 & $\begin{array}{l}\text { Zhang et al. } \\
\text { (2007) }\end{array}$ \\
\hline \multirow[t]{2}{*}{ IV } & $\begin{array}{l}\text { Beipei, } \\
\quad \text { Chongqing }\end{array}$ & 13 & $\begin{array}{l}\text { Paddy rice- } \\
\text { rapeseeds }\end{array}$ & No & -66.76 & -35.80 & 309.6 & $\begin{array}{r}\text { Tang et al. } \\
(2007 \mathrm{~b})\end{array}$ \\
\hline & & 13 & & Reduced & -66.76 & -62.50 & 42.65 & \\
\hline
\end{tabular}

\section{References}

Chen DZ (2000) Effects of paddy rice straw return on soil physical and chemical property and crop yield. Soils and Fertilizers, 2000, 24-27 (in Chinese).

Chen SZ, Yang BJ, Song GY, Wei CF, Yuan L, Gao M (1995) Effects of paddy rice straw return on soil fertility and yield. Soils and Fertilizers, 1995, 13-17 (in Chinese).

Chen XB, Zou ZR (2005) Dry Yuan of River West Corridor which has long-term location fertilizer increase soil properties and the production of spring wheat. Chinese Journal of Soil Science, 36, 888-890 (in Chinese).
Chen ZM, Zhou CS, Yao ZH, et al. (1996) Brief report of monitoring study on the fertility of drab fluvoaquic soil in Beijing. Soils and Fertilizers, 1996, 6-11 (in Chinese).

Dai TG, Wang ZW, Cheng GH, Hua JS (2001) Effects of barley field paved with rice straw and its application. Barley Science, 2001, 28-29 (in Chinese).

Dang TH, Peng L, Dai MJ, Li Q (1993) Effect of long-term fertilization on both soil nutrient and crop yield of dry high land. Bulletin of Soil and Water Conservation, 13, 78-82 (in Chinese).

Fan J, Hao MD, Wang YG (2003) Effects of rotations and fertilizations on soil fertility on upland of Loess Plateau. Research of Soil and Water Conservation, 10, 31-36 (in Chinese). 
Fan TL, Stewart BA, Wang Y, Luo JJ, Zhou GY (2005) Long-term fertilization effects on grain yield, water-use efficiency and soil fertility in the dryland of Loess Plateau in China. Agriculture, Ecosystems \& Environment, 106, 313-329.

Fan XW, Chi BL (1993) Study on straw mulching in saline land for higher yielding and soil amendment. Agricultural Research in the Arid Areas, 11, 13-18 (in Chinese).

Gao YC, Zhu WS (1994) A study on soil micro biomass and fertilization nutrient transformation under zero tillage with straw mulching. Scientia Agricultura Sinica, 27, 41-49 (in Chinese).

Gao YJ, Zhu PL, Huang DM, Wang ZM (2000) Long-term impact of different soil management on organic matter and total nitrogen in rice-based cropping system. Soil and Environmental Sciences, 9, 27-30 (in Chinese).

Gu QZ, Yang XY, Sun BH, Ma LJ, Tong YA, Zhao BQ, Zhang FD (2004) Effects of long-term fertilization and irrigation on soil nutrient distribution in profiles of Loess soil. Chinese Agricultural Science Bulletin, 20, 139-142, 147 (in Chinese).

Guan WL, Wang XD, Li LM, Wei DL (2002) Study on the properties and existing state of the soil humus under different long-term fertilizations. Agricultural Research in the Arid Areas, 20, 32-35 (in Chinese).

Han XR, Chen EF, Guo PC, Zou DY (1995) Effects of long term fertilization on crop yield and soil nitrogen fertility. Chinese Journal of Soil Science, 26, 244-246 (in Chinese).

Hou ZY, Du GJ, Sun ZX, Zheng JM, Yu XC, Hui CZ, Li Z, Wang SL (2004) Study on effect of turning over maize straw into soil. Rain Fed Crops, 24, 166-167 (in Chinese).

Huang B, Wang JG, Jin HY, Xu SW (2006) Effects of long-term application fertilizer on carbon storage in calcareous meadow soil. Journal of Agro-Environment Science, 25, 161-164 (in Chinese).

Jiang WX, Zhou GY (1994) Effect of crop straw return on the fertility improvement of Calcic Kastanozems. Gansu Agricultural Science and Technology, 1994, 25-26 (in Chinese).

Jin CL, Quan YJ, Ma YF, Jin XJ, Fang JX (1993) A brief report on a position experiment of paddy rice straw return. Heilongiang Agricultural Science, 1993, 21-23 (in Chinese).

Jin SL, Ma YT (1995) Primary study on long-term effect of application of different fertilizer on the crop production and soil fertility. Gansu Agricultural Science and Technology, 1995, 23-25 (in Chinese).

Lai QW, Li CG, Huang QH (1992) Effect of continuous application of inorganic fertilizer on soil structure properties of paddy soil derived from red soil. Acta Pedologica Sinica, 29, 168-174 (in Chinese).

Li KJ, Ma JY, Cao CY, Zheng CL, Sun WF (2007) Effect of the long-term different organic fertilizer applications on crop yield and soil properties. Journal of Hebei Agricultural Sciences, 11, 60-63 (in Chinese).

Li SJ, Xu SM (1987) Effects of crop straw on increasing soil organic matter. Soils and Fertilizers, 1987, 14-15 (in Chinese).

Li WX (2007) Effects of fertilization on Lou-soil fertility and yield. Soil and Fertilizer Sciences in China, 2007, 23-25 (in Chinese).

Lin Y, Lin Z (1994) Effect of paddy rice straw return on soil fertility and yield. Fujian Agricultural Science and Technology, 1994, 8-9 (in Chinese).
Lin YJ, Lin ZQ (1994) Effect of paddy rice straw return on soil fertility and yield. Fujian Agricultural Science and Technology, 1994, 8-9 (in Chinese).

Liu EK, Zhao BQ, Hu CH, Li XY, Li YT (2007) Effects of longterm nitrogen, phosphorus and potassium fertilizer applications on maize yield and soil fertility. Plant Nutrition and Fertilizer Science, 13, 789-794 (in Chinese).

Liu JL, Wang CZ, Zhao SL, Wang FX, Sun GM (1990) Primary study of effects of paddy rice straw return on soil fertility and yield. Jilin Agricultural Sciences, 1990, 70-72 (in Chinese).

Liu JL, Zhao SL, Wang CX, Sun GM, Wang FX, Liu YW, Ren CL (1992) Study on fertility improvement and fertilizer efficiency in paddy field. Soils and Fertilizers, 1992, 20-22 (in Chinese).

Liu JR, Liu YH, Zhang DY, Guo ZC (1984) Influence of straw return on paddy field soil fertility and growth of paddy rice. Chinese Journal of Soil Science, 15, 49-53 (in Chinese).

Liu SP, Shen XP (1996) A study on soil nutrient supplying capability and fertilizer absorbing law of paddy rice under long-term zero or reduced tillage treatment. Chinese Journal of Soil Science, 27, 133-135 (in Chinese).

Liu ST, Han XR, Yao YX, Sui FG (2005) Effects of long-term located fertilization on water holding and humus constitution of the non-calcareous fluvo-aquic soil. Chinese Agricultural Science Bulletin, 21, 272-274, 277 (in Chinese).

Liu XH, Zou DY, Kang XF, Zhou CJ, Liu YJ (1998) Influence of long-term rotation and fertilization on soil organic matter and its components. Journal of Shenyang Agricultural University, 29, 53-58 (in Chinese).

Liu Y (2003) Influences of fertilization on the yield of winter wheat and soil fertility in dryland of Loess Plateau. Research of Soil and Water Conservation, 10, 40-42 (in Chinese).

Liu YW, Ren CL, Liu JL, Wang CX, Zhao SL, Sun GM, Wang FX (1991) Effect of straw return and synthetic NPK fertilizer application in paddy soil on yield increase. Journal of Jilin Agricultural University, 13, 45-49 (in Chinese).

Liu ZX, Yang ZH, Qiu XX, Liu YH, Lin YJ, Zhuang SY, Fang H, Lin ZQ (1994) Contribution of fertilizers to yield increase and its effect on soil organic matter. Plant Nutrition and Fertilizer Science, 1994, 19-26 (in Chinese).

Ma JY, Li KJ, Cao CY, Zheng CL (2007) Effect of long-term located organic-inorganic fertilizer application on fluvo-aquic soil fertility and crop yield. Plant Nutrition and Fertilizer Science, 13, 236-241 (in Chinese).

Meng L, Cai ZC, Ding WX (2005) Carbon contents in soils and crops as affected by long-term fertilization. Acta Pedologica Sinica, 42, 769-776 (in Chinese).

Mu L, Zhang JH, Guan LZ (1998) Changes of soil organic matter under different cultivation. Journal of Shenyang Agricultural University, 29, 59-64 (in Chinese).

Niu LA, Qin YS, Hao JM, Niu XS (1998) Effect of straw return combined with nitrogen and phosphorus fertilizer application on soil fertility and crop yield in Quzhou experiment district. Soils and Fertilizers, 1998, 32-35 (in Chinese).

Qian HB, Han CG, Qian CJ, Yan GZ (1998) The study on the techniques of wheat and paddy straw-returned-native-field. Soils and Fertilizers, 1998, 26-28 (in Chinese).

Qin HL, Gao WS, Li CY (2007) Impacts of no-tillage on soil temperature of field in Ecotone of North China. Transactions of 
the Chinese Society of Agricultural Engineering, 23, 40-47 (in Chinese).

Qin JH (2005) Effects of non-tillage and mulching on soil building of desertified soil in the Hexi Corridor. Soils, 37, 447-450 (in Chinese).

Qiu HC, Liu PC, Li XY, Wang QF, Xu FL (1998) Returning application of straw and the state of organo-mineral complexing in paddy soils. Plant Nutrition and Fertilizer Science, 4, 92-96 (in Chinese).

Ren ZG, Tang FQ, Wang DH, Zhang YQ (1993) Effect of organic and inorganic fertilizer combination on rice productivity and soil fertility. Journal of Fujian Academy of Agricultural Sciences, 8, 23-29 (in Chinese).

Shi Y, Lu CY, Zheng J, Chen X (2002) Effect of different fertilization and tillage treatments on POM-C in black soil. Chinese Journal of Ecology, 21, 71-73 (in Chinese).

Song YL, Tang HJ, Li XP (2007) The effects of long-term fertilization on crop yield and aqui-cinnamon soil organic matter. Acta Agriculturae Boreali-Sinica, 22 (Suppl.), 100-105 (in Chinese).

Song YL, Yuan FM, Yao ZH (2002) Effect of combination of NPK chemical fertilizer and different organic materials on crop yield and soil organic matter. Acta Agriculturae Boreali-Sinica, 17, 73-76 (in Chinese)

Sun GY, Zhao SR, Zhu WB, Zhang YC, Wang SP, Zhang HC (1996) Effects of long-term application of chemical fertilizers on soil and crop yields in Xuhuai Patch-alkali soil district. Jiangsu Journal of Agricultural Sciences, 12, 16-25 (in Chinese).

Sun HD, Li J, Shang HX, Zhu P, Liu SH, An WH, Song YR, Wu GL (1992) Position monitoring of soil fertility and fertilizer benefit of Mollisols soil - the second report: effects of maize stalk returning on Mollisols soil fertility and crop yield. Jilin Agricultural Sciences, 1992, 40-42 (in Chinese).

Sun KG, Wang LG (2002) Effect of different fertilization practices on yield of a wheat-maize rotation and soil fertility. Pedosphere, 12, 283-288

Sun KG, Zhang GL, Wang Y, Cui ZL, Zhang XB (1999) Response to yield and soil fertility of rotation between wheat and maize (soybean) on the permanent fertilization of NPK fertilizer Chinese Agricultural Science Bulletin, 15, 18-23 (in Chinese).

Sun R, Zhao B, Zhu L, Xu J, Zhou Q, Zhang F (2003) Effects of long-term fertilization on soil enzyme activities and its role in adjusting-controlling soil fertility. Plant Nutrition and Fertilizer Science, 9, 406-401 (in Chinese).

Sun TC, Li SQ, Shao MA (2005) Effects of long-term fertilization on distribution of organic matters and nitrogen in Cinnamon soil aggregates. Scientia Agricultura Sinica, 38, 1841-1848 (in Chinese).

Sun WL, Wang LD, Jin JS, Zhou CS (1994) Effects of straw returning to the periodical water-logging soil humus in Suzhou district. Chinese Journal of Soil Science, 25, 172-174, 177 (in Chinese).

Tan YY, Dong JH, Liu JH, Wei CH, Tan YE, Huang JQ (1990) Effect of compound or mixed fertilizer application on paddy rice yield and soil fertility. Soils and Fertilizers, 1990, 22-25 (in Chinese).

Tang XH, Shao JA, Gao M, Wei CF, Xie DT, Pan GX (2007a) Effects of conservational tillage on aggregate composition and organic carbon storage in purple paddy soil. Chinese Journal of Applied Ecology, 18, 1027-1032 (in Chinese).
Tang XH, Shao JA, Huang XX, Wei CF, Xie DT, Pan GX (2007b) Distribution of soil organic carbon in purple paddy field under long-term non-tillage ridge culture. Acta Pedologica Sinica, 44, 235-243 (in Chinese).

Tian XP, Tao YX, Wang LJ, Ji JH (2002) The effect of different cultivating on nutrient and crop yield in albic soils. Journal of Heilongjiang August First Land Reclamation, 14, 9-11 (in Chinese).

Wang CR, Yang XY, Zhang FS (2000a) Study on the effects of fertilization on soil organic matter. Shaanxi Agricultural Sciences, 2000, 13-15 (in Chinese).

Wang DZ, Guo XS, He CL, Liu F (2007) Effect of long-term fertilization on wheat growth and soil nutrition status in Shajiang Black Soil. Chinese Journal of Soil Science, 38, 55-57 (in Chinese).

Wang KR, Liu X, Zhou WJ, Xie XL, Buresh RJ (2004) Effects of nutrient recycling on soil fertility and sustainable rice production. Journal of Agro-Environment Science, 23, 1041-1045 (in Chinese).

Wang XB, Yang CX, Xie QY (2004) Primary report on study of different combinations of tillage and straw returning amount. Shanghai Agricultural Science and Technology, 6, 13-14 (in Chinese).

Wang XD, Shi XJ, Song GY (2005) Effects of long-term rice straw returning on the fertility and productivity of purplish paddy soil. Plant Nutrition and Fertilizer Science, 11, 302-307 (in Chinese).

Wang XD, Zhang YP, Lü JL, Fan XL (2000b) Effect of long term different fertilization on properties of soil organic matter and humic acids. Scientia Agricultura Sinica, 33, 75-81 (in Chinese).

Wang ZZ, Wu JM, Chen LG, Zhu PP (2003) Effects of direct and whole straw manuring method on increasing yield of crop and fertility of soil in rice-wheat double cropping area of Taihu Lake district. Jiangsu Journal of Agricultural Sciences, 19, 151-156 (in Chinese).

Wu S (1996) Study on continuous cropping of maize and long-term fertilization. II: Effects of continuous fertilization on maize quality and soil fertility. Liaoning Agricultural Sciences, 1996, 7-12 (in Chinese).

Wu TY, Schoenau JJ, Li FM, Qian PY, Malhi SS, Shi YC, Xu FL (2004) Influence of cultivation and fertilization on total organic carbon and carbon fractions in soils from the Loess Plateau of China. Soil \& Tillage Research, 77, 59-68.

Wu ZJ, Zhang HJ, Xu GS, Zhang YH, Liu CQ (2002) Effect of returning corn straw into soil on fertility. Chinese Journal of Applied Ecology, 13, 539-542 (in Chinese).

Xiao WW, Fan XH, Yang LZ, Hao MD (2007) Response of soil organic nitrogen forms and organic carbon to long-term fertilization in dry highland of Loess Plateau. Journal of Agro-Environment Science, 26, 672-675 (in Chinese).

Xie LH, Lv JL, Zhang YP, Liu XW, Liu LH (2004) Influence of long-term fertilization on phosphorus fertility of calcareous soil: I. Organic matter, total phosphorus and available phosphorus. Chinese Journal of Applied Ecology, 15, 790-794 (in Chinese).

Xu MG, Yu R, Sun XF, Liu H, Wang BR, Li JM (2006a) Effects of long-term fertilization on labile organic matter and carbon management index (CMI) of the typical soils of China. Plant Nutrition and Fertilizer Science, 12, 459-465 (in Chinese). 
Xu MG, Yu R, Wang BR (2006b) Labile organic matter and carbon management index in red soil under long-term fertilization. Acta Pedologica Sinica, 43, 723-729 (in Chinese).

Yan L, Song Y, He J, Chen Y, Zhang J, Bao YY, Guan LZ (2004) Effects of maize stems returning back to the field on the yield of plants and soil fertility. Chinese Journal of Soil Science, 35, 143-148 (in Chinese).

Yang B, Chen XB, Yang DJ (2005) The influence of location fertilization for irrigated desert soils in Gansu corridor on soil fertility and output of spring wheat. Soil and Water Conservation in China, 2005, 35-37 (in Chinese).

Yang ZP, Zhou HP, Li HM, Wang JZ, Ma YZ (1999) Effect of straw returned to field on dryland soil fertility and the growth of corn. Agricultural Research in the Arid Areas, 17, 10-15 (in Chinese).

Yin DM, Xie FG, Jing JF, Zu SX (1995) Effect of long-term paddy rice straw returning on fertility improvement and K-supplying. Chinese Journal of Soil Science, 26, 253-256 (in Chinese).

Yuan JG, Li BM, Wan JM, Ren LX (2004) Research of protecting cultivation in the northwest arid area of Shanxi Province. Journal of Shanxi Agricultural University (Natural Science Edition), 24, 347-350 (in Chinese).

Yuan L, Yang BJ, Huang JG, Zheng LJ, Liu XC (1993) Effects of long-term organic and synthetic fertilizer application on soil organic matter and soil nitrogen. Journal of Southwest Agricultural University, 15, 314-317 (in Chinese).

Zeng GJ, Fu SZ, Liu YH, Jin P, Zhang X, Zhao G (1985) Influence of straw return on crop yield and soil quality. Heilongiang Agricultural Science, 1985, 10-14 (in Chinese).

Zeng HJ, Wang ZP, Hu CS, Zhang YM (1996) The characters of soil organic matter decomposition and accumulation in the semi-moist district of North China. Soils and Fertilizers, 1996, 1-4 (in Chinese).

Zhang AJ, Zhang MP (2002) Study on regularity of growth and decline of soil organic matter under long-term fertilization for yellow fluvo-aquic soil. Journal of Anhui Agricultural University, 29, 60-63 (in Chinese).

Zhang BY, Li JS, Zhang SF, Qu SL, Wu RD (1989) Primary study of effect of organic and inorganic fertilizer application on crop yield and soil organic matter. Soils and Fertilizers, 1989, 36-38 (in Chinese).

Zhang DX, Han ZQ, Wang JY, Chen HB, Zhu XP (1999) Study on the technical regulation of straw directly returning to field in cinnamon soil in eastern areas of Hebei Province. Journal of Hebei Vocation-Technical Teachers College, 13, 1-6 (in Chinese).

Zhang GY, Sun SY, Zhang ZP, Jia SL, Zhao TK (2000) Studies on the effects of fertilization, tillage, residues management and herbicide application on soil quality. Journal of Hebei Agricultural Sciences, 4, 16-22 (in Chinese).

Zhang LJ, Zhang HY, Dong QH (1991) A report on a long-term paddy straw return experiment. Journal of Zhejiang Agricultural Sciences, 1991, 84-86, 98 (in Chinese).
Zhang R, Yan HJ, Wei YQ, Shan XZ, Liu JF (1997) Effect of organic fertilizer application on saline soil amendment. Soils and Fertilizers, 1997, 11-14 (in Chinese).

Zhang XZ, Li TX, Yu HY, Zhou JX, Wu DY (2006) Effects of longterm natural no-tillage on soil physiochemical properties in rice/wheat rotation systems. Journal of Soil and Water Conservation, 20, 145-147 (in Chinese).

Zhang YF, Zhong WH, Li ZP, Cai ZC (2006) Effects of long-term different fertilization on soil enzyme activity and microbial community functional diversity in paddy soil derived from quaternary red clay. Journal of Ecology and Rural Environment, 22, 39-44 (in Chinese).

Zhang ZJ (1989) Effect of organic and inorganic fertilizer application on fertility of the grass dark brown soil. Heilongjiang Agricultural Science, 1989, 8-12 (in Chinese).

Zhang ZJ (1998) Effect of long-term wheat stalk return on soil fertility and yield. Chinese Journal of Soil Science, 29, 154-155 (in Chinese).

Zhao XL, Xu DZ, Gao Y (1998) A brief report on effects of maize root straw return to soil fertility. Chinese Journal of Soil Science, 29, 14-16 (in Chinese).

Zhao YY, Xie YS, Hao MD (2007) Yield effects and soil fertility evolution of long-term application of fertilizer on wheat in dry land of Loess Plateau. Acta Agriculturae Boreali-occidentalis Sinica, 16: 75-79, 88 (in Chinese).

Zheng JY, Wu RJ (1995) Effects of long-term applying soil fertilizer and changes of soil nutrient. Bulletin of Soil and Water Conservation, 15, 14-18 (in Chinese).

Zheng LC, Xie HT, Zhang W, Zhang XD (2006) Effects of different ways of returning straw to the soils on soluble organic carbon. Ecology and Environment, 15, 80-83 (in Chinese).

Zhou B, Qiao M, Wang ZQ (2007a) Effects of a long-term located fertilization on soil quality of grey desert soil. Chinese Journal of Eco-Agriculture, 15, 33-36 (in Chinese).

Zhou B, Wang ZQ (2003) Effects of long-term located fertilization on soil nutrient in the farmland ecosystems of grey desert soil oases. Agricultural Research in the Arid Areas, 21, 35-39 (in Chinese).

Zhou H, Lv YZ, Yang ZC, Li BG (2007b) Effects of conservation tillage on soil aggregates in Huabei Plain, China. Scientia Agricultura Sinica, 40, 1973-1979 (in Chinese).

Zhou JB, Li CW, Zhao BS, Hua TM, Li HT (1993) Effects of longterm fertilization on nutrients of Lou subsoil. Chinese Journal of Soil Science, 24, 21-23 (in Chinese).

Zhou WJ, Wang KR, Zhang GY, Xie XL (2002) Contribution of fertilization development in rice-yield increase and effects on soil fertility in red paddy area. Chinese Journal of Soil Science, 33, 197-201 (in Chinese).

Zhou ZH, Ni XW (1995) Effects of long-term early paddy straw return on late paddy rice. Jiaxing Agriculture, 1995, 28-30 (in Chinese). 